\title{
Article \\ Social Media and Political Communication of Youth Political Organisations in Slovakia, Czechia and European Level: A Cross-Case Analysis
}

\author{
Jaroslav Mihálik*(D), Michal Garaj and Jakub Bardovič $\mathbb{D}$
}

check for

updates

Citation: Mihálik, Jaroslav, Michal

Garaj, and Jakub Bardovič. 2022.

Social Media and Political

Communication of Youth Political

Organisations in Slovakia, Czechia

and European Level: A Cross-Case

Analysis. Social Sciences 11: 69.

https: / / doi.org/10.3390/

socsci11020069

Academic Editor: Daniel Stockemer

Received: 21 December 2021

Accepted: 9 February 2022

Published: 12 February 2022

Publisher's Note: MDPI stays neutral with regard to jurisdictional claims in published maps and institutional affiliations.

Copyright: (C) 2022 by the authors. Licensee MDPI, Basel, Switzerland. This article is an open access article distributed under the terms and conditions of the Creative Commons Attribution (CC BY) license (https:// creativecommons.org/licenses/by/ $4.0 /)$.
Faculty of Social Sciences, University of Ss. Cyril and Methodius, 91701 Trnava, Slovakia; michal.garaj@ucm.sk (M.G.); jakub.bardovic@ucm.sk (J.B.)

* Correspondence: jaroslav.mihalik@ucm.sk

\begin{abstract}
This is an exploratory cross-case analysis of political communication strategies of selected youth political organizations on the social network Facebook. The main objectives of this paper are to capture the topics and frequency of posting of Youth Political Organization on Facebook. Secondary, the study aims to capture the analytical approach categories/objectives: themes and actors. It focuses on the 3-month period from December 2020 to February 2021. Relevant youth political organizations in Slovakia and the Czech Republic are compared with youth political organizations operating at the European level. The organizations either belong directly to the kin political party or have the status of a supporting organization. At the European level, they are also affiliated to a European political party or are a supporting organization of a European political party. The data source is the official profiles of youth political organizations on the social network Facebook. Data processing is based on content analysis of published posts. Content analysis focuses on topics, the frequency of topics, the occurrence of keywords in the overall set of posts, and identifying attitudes to topics. The obtained data are evaluated by descriptive statistics. The presentation of the data is supplemented by tables, including graphical processing using the Voyant Tools text analysis tool. Key findings indicate that COVID-19 pandemic is the most communicated topic both on national and European level. Czech and Slovak cases seek to gain support or create conflict based on selected topics, while European level forms an area of cooperation among organizations.
\end{abstract}

Keywords: social media; political communication; youth political organization; Facebook

\section{Introduction}

Political communication is, as Norris (2015) points out, an interactive process in which information is exchanged between political actors, especially politicians; the media; and the public (voters). The flow of information itself is realized in several directions (cf. Norris 2015). Its importance for society is indirectly visible through the great interest of the authors in this topic, which is also shown in the following lines. In addition, it merges or is directly linked to other areas of political life, such as the political campaign, which opens up other topics and sub-themes. This study is framed in the field of political communication, and specific attention is paid to the form of communication of youth political organizations within Slovakia, the Czech Republic, and the European level on the social network Facebook.

Recent years have brought fundamental technological innovations that have also affected political communication and opened a new paradigm in its research (Allcott and Gentzkow 2017). As a result, an important part of the exchange of information between politicians and voters has gradually moved to the online environment. In addition, some studies show that the use of certain online tools can support selected attributes of democracy, such as political participation (e.g., de Zúñiga et al. 2012) or political (internal) efficacy (Moeller et al. 2014). Bagić Babac and Podobnik (2018) state that social media enables 
politicians to engage constituents in a two-way and symmetrical communication while providing politicians to better represent opinions of the people they represent. It is even possible to find politicians who have decided to use social media to express fundamental political views. Among the world leaders, we may include the US ex-president Donald Trump and his famous tweets on the social network Twitter. Social networks have thus become an essential part of political communication and campaigns, changing their form, how they exchange and obtain information about politics or form opinions and attitudes (see also: Dimitrova and Matthes 2018). Therefore, we can briefly state what several authors have pointed out, e.g., Klinger and Svensson (2015), that social networks have changed the form of political communication. However, the content itself and users' access to social networks or online platforms have evolved over time. Although, as Papacharissi (2004) points out, communicated content at the beginning of the millennium may have shown signs of politeness and civility, nowadays this environment has changed greatly and we see several negative elements here, including the spread of hatred or misinformation, multiplied by the current pandemic scenario. This fact simultaneously sparked a discussion about the possible need to limit or regulate this form of communication (e.g., Guiora and Park 2017).

Social media have opened up a new area of research (Magin et al. 2016), which is addressed in several scientific disciplines that underline the very essence of political communication as an interdisciplinary field of potential research interest (Kaid 2004). In addition, its transformation from a static to an interactive form, where the position between the author and the addressee can actively change, has opened up further space for scientists and knowledge in this area (Stier et al. 2018). However, this change has also brought some issues that need to be addressed. New media, specifically social media, in some respects, requires a specific approach and methodology for learning about them, since they involve fluidity of content; innovation; a wealth of resources; and, last but not least, questions of their relevance (Kyška 2014). In addition, social media create space for the existence of a certain paradox; on the one hand, political communication and thus political campaign is exposed to professionalization, which logically opens up a new area of research, including ambitions to capture this phenomenon in research (e.g., Ostrá 2021), but at the same time offers individual political actors intuitive and spontaneous communication without the support of an expert/adviser.

Research in this area is relatively rich and several studies have been carried out in recent years. Brunnerová and Charvát (2017) state, based on their follow-up of nine journals over the course of 8 years, that the authors' interest in new media has increased in recent years. On the one hand, the interest of scientists has focused on specific social media in the context of political communication, such as Facebook (e.g., Gerodimos and Justinussen 2014; Ceccobelli 2018), Twitter (e.g., Cervi et al. 2021a; López-Meri et al. 2017) or newer communication tools such as TikTok (e.g., Cervi et al. 2021b; Cervi and Marín-Lladó 2021), as well as for comparative or at least simultaneous monitoring of several social media platforms (e.g., Stieglitz and Dang-Xuan 2012; Bossetta 2018; Haro-de-Rosario et al. 2018). In a large group of these studies, the interest is the presence of specific political actors or using communicated content analysis to find out how they are used. However, some also seek the role of these new media with regard to democracy or political participation (Haro-de-Rosario et al. 2018), or electoral period and the associated election campaign. It is therefore appropriate to mention their role in the election campaign. The importance for monitoring this fact stems from the fact that the communication of the non-election period and in the period before the elections differs, which is pointed out, for example, in research of 18 states by Ceccobelli (2018).

Social media campaigning has also reached European Parliament elections in 2014 (Nulty et al. 2016), great attention is also paid to the US presidential election (e.g., focused on one candidate-Obama), or more candidates and several networks (Gerodimos and Justinussen 2014; Bossetta 2018) or elections in Central and Eastern Europe, e.g., the Czech Republic (Filipec 2018) or Romania (Momoc 2018). 
Looking at up to date research, we find mainly data reflecting communication of political parties (López-Meri et al. 2017; Cervi and Marín-Lladó 2021), specific authorities or local governments (e.g., Haro-de-Rosario et al. 2018), or individuals/politicians (e.g., Gerodimos and Justinussen 2014; Bossetta 2018). However, as we mentioned above, there is currently no research on the political communication of a specific type of political organization, namely youth organizations, which only underscores the importance of this study. Political communication research in Slovakia is not limited to e-forms and includes a relatively wide range of monitored areas. There are several studies that have followed, for example, political discussions in key discussion sessions. Plichtová and Šestáková (2019) drew attention to the presidential candidates and their communication strategies, and Mihálik and Jankol'a (2020) to party leadership of individual political parties. We also monitor political communication indirectly, for example through research into specific media. Duffeková (2020) focused her attention on the prime time news programs of key Slovak televisions and the presence of representatives of individual political parties in them. At the same time, its findings confirmed a long-discussed topic, namely their unequal approach to specific subjects.

Slovakia is considered as an importer of innovative ideas or elements. As the basic ideological concepts shaping the political sphere gradually shifted (Gbúrová 2006), this also happened in connection with political communication. Individual political actors only gradually discovered these new possibilities of addressing voters and their integration into communication strategies was thus implemented at a certain distance. As a result, they did not reach their full potential in a particular period of time (Bratková 2015; Žúborová and Žúbor 2013). Ondrášik (2009) already attributed a certain role to the Internet in the presidential elections held in 2009 and drew attention to its use in the campaign, including by the media themselves. We also encounter the use of the social network Facebook in studies where e-communication and social networks are one of the monitored areas (Lincényi and Čársky 2019; Jánošová and Bundzíková 2020). The growing importance of e-communication is also transformed by the very focus of research reflecting the Slovak context, which makes it a legitimate research topic for independent research of social networks (Garaj 2018; Kluknavská and Hruška 2019), websites (Žúborová and Žúbor 2013), or blogs (Imrovič et al. 2018). There are often combinations of social networks and websites (Filipec et al. 2018). The findings of Smolková and Štarchoň (2019), who identified social media as an important element of the election campaign, especially in the group of voters under the age of 30 , show the importance of monitoring this issue. There is a large number of studies focused only on the conditions of Slovakia (Murár 2011; Bardovič 2018; Garaj 2018; Garaj and Bardovič 2020). A separate space can be defined for studies that went the way of mutual comparison of two nearby countries, namely Slovakia and the Czech Republic (Mihálik and Walter 2018; Filipec et al. 2018). We can find more extensive comparative studies involving several countries, including Slovakia (Annusewicz and Morawski 2014).

There is a relatively important position of research devoted to political parties' communication (Garaj 2018; Kluknavská and Hruška 2019), which have an irreplaceable place in the Slovak political system. In addition, we find studies focused on specific politicians or institutions (Bardovič 2018; Bratková 2015), as well as local governments (Mital' 2021). However, we also find specific research objects, for example, Daško (2018) addressed local action groups and their activities on the social network Facebook in his article. However, very few studies can be found in the Slovak environment dedicated to youth political organizations. A recent study reflecting the period of the COVID-19 pandemic by Mihálik et al. (2020) offered a direct focus on their Internet communication with a stronger emphasis on the social network Facebook. Mihálik and Džačovský (2018) were interested in youth organizations and the influence of Europeanization on their communication on the Facebook network. Their findings showed that this effect was manifested only to a small extent. It is this research deficit that forms the basis for the creation of further studies that 
will pay attention to this area and draw attention to how potential future representatives of political parties communicate.

\section{Materials, Methods and Goals: Social Media Analytics Framework}

The applied initial framework for the evaluation of political communication on social networks follows Stieglitz and Dang-Xuan's (2012) model which consists of two main parts: 1. data monitoring and tracking and 2. data analysis. Monitoring determines three steps to specify the data collection: tracking sources, tracking methods, and data types. Tracking sources offer opportunities to focus on weblogging (classic website blogs) or microblogging platforms (social networks), while the authors themselves have adapted their analytics framework to the microblogging environment of social networks (examples are given primarily by Facebook and Twitter).

Tracking methods for data tracking microblogs offer API (application programming interfaces) procedure. The Search API and Streaming API designed primarily for Twitter, and the Graph API designed for Facebook allow us to collect data and information published on the walls of selected profiles. Data types are divided into structured and unstructured categories. Structured data types (categorized + primary quantitative) are e.g., socio-demographic indicators about users on a specific site; interactions on posts-"likes", "shares", "comments", "clicks", "tags" or "types of posting"; or (outside "content of comments"). Unstructured data (primary text) represent published posts/texts of the site owner ("wall text content") or users who come to the site ("comments content"). Data tracking is based on five possible approaches ("tracking approaches"), while it is possible to select one specific approach or more. At the same time, various possibilities and combinations of used tracking approaches arise. The Self-Involved Approach is usable if the site owner (politician or entity/political party) wants to know exactly how users on the social network interact. Through keywords and hashtags, they can access a set of posts that mention their names or the names of political parties. The Keyword/Topic-based Approach can select through a set of (data) posts dedicated only to specific thematic content.

The scope of the data set determines the number of keywords identified or specified. The Actor-based Approach focuses on actors-personalities (politicians) or entities (political parties) who can influence the formation of public opinion (opinion-making process) in the social network environment. The data set is created based on the selection of the actor (s) to which attention is drawn. Based on a specifically compiled data file, the Random/Exploratory Approach tries to identify it through content analysis, e.g., the most frequently used topics, the most frequently used words, the most frequently mentioned actors or users in published texts. The process seeks to identify the key starting points and contexts integrated into the dataset. The URL-based Approach focuses on a data set of posts in which URL links to other content are shared and linked (web, social media posts: "retweet", "share content", sharing links from other social networks: Youtube). A visual view of the Data Tracking and Monitoring process as introduced by Stieglitz and Dang-Xuan (2012) is presented in Table 1.

After selecting the data source platform and setting the data tracking access in the first phase, the selection of access methods to data analysis follows Analysis Approaches Methods. The analytical framework offers a choice of four main types of approaches, which can also be implemented in parallel: topic/issue-related approach; opinion/sentimentrelated approach; actor-related approach; and network-related approach. The topic/issuebased approach aims at understanding the communication policy issues or issues that are currently being published. 
Table 1. Data Tracking and Data Monitoring. Source: Stieglitz and Dang-Xuan (2012, p. 16).

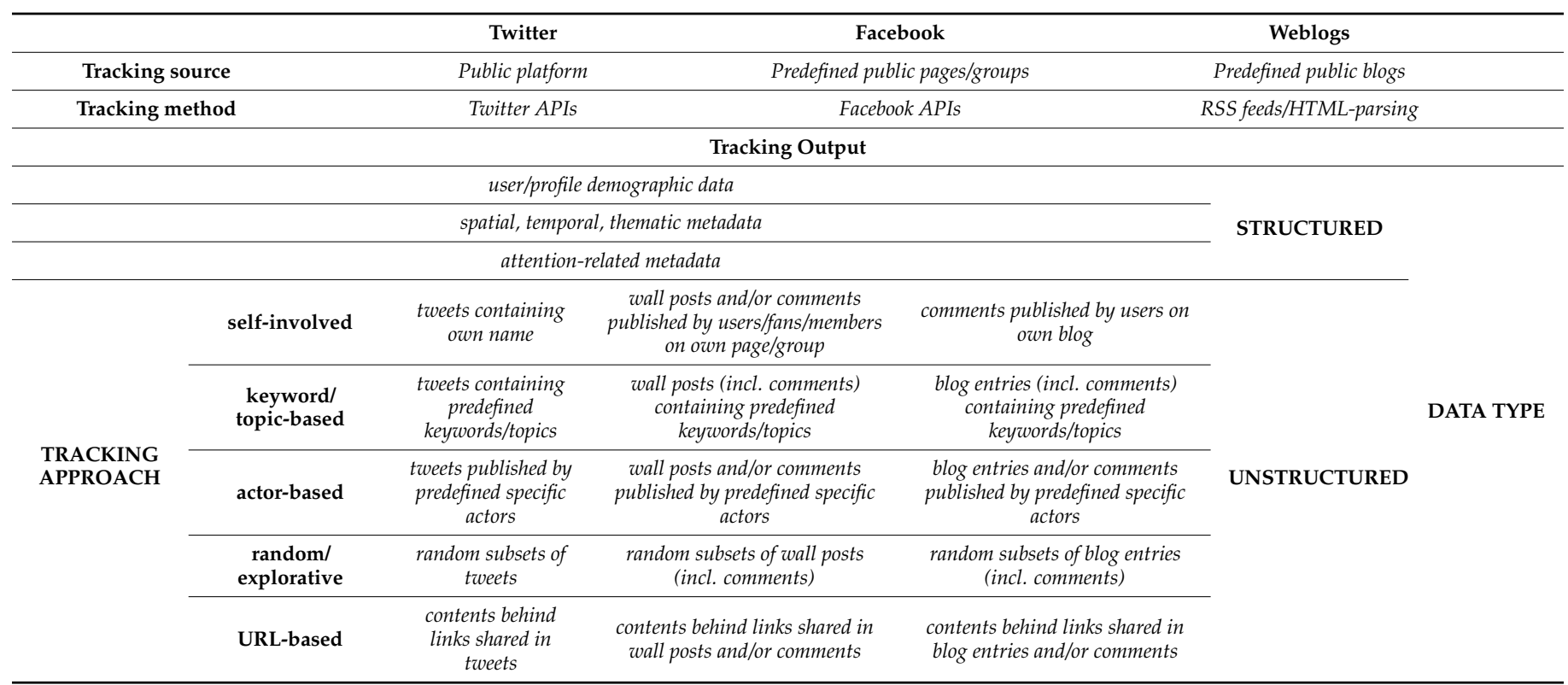

Different topics can be a source of conflict or cooperation with other politicians or political parties. Communication of current trends is also essential for politicians and entities. Content analysis of the text is proposed as a research strategy/technique for successful identification of topics. Manual or automatic term search can be used. Opinion/sentimentrelated approach evaluates opinion and attitude opinions on a selected issue or entity.

The aim of the approach is to collect a set of data with opinions from other representatives, entities, or the public. Content analysis of texts (wall-posts, comments) is again proposed as a suitable research strategy/technique. The actor-based approach focuses on identifying actors who may be potential supporters or opponents. The approach is based on a content analysis technique that seeks to find all the actors who mention the policy or entity in their contributions. The aim is to focus on actors who have opinion-forming potential or social influence. The network-based approach aims to detect target populations or communities that mention the actor. Advanced text analysis and user profiles can identify their common characteristics (e.g., economic status, age, gender, and interests). The scheme of approaches for data analysis with procedures and techniques based on Stieglitz and Dang-Xuan (2012) is summarized in Table 2.

Our study is not based on any specific theory related to political communication. We do not seek to confirm or verify certain hypotheses because of lack of previous results to follow. For that reason, the study has exploratory character and seeks to identify the main issues related to political communication of YPOs on social networks. This approach is chosen on the processed literature review that proved the absence of wide results in the political communication of the YPOs. Second, we apply the Stieglitz and Dang-Xuan (2012) social media analytics framework and explanatory analysis approach. The primary objective of the study is to identify communication strategies between youth political organizations on the social network platform Facebook. The reason for choosing Facebook as the source of data and platform for analysis is due to higher interaction in Czech and Slovakia region on Facebook. Slovak and Czech YPOs communicate more frequently and publish larger content on Facebook in comparison with other social networks such as Instagram, TikTok, or Twitter. Another important reason is the fact that not all relevant YPOs have active accounts on Instagram (Mihálik et al. 2020), TikTok, or Twitter. Facebook allows researchers to have a more complete data set. Second, the study aims at two analytical approach categories/objectives: themes and actors. The topics monitoring tries to clarify the main communicated frameworks and explore "hot topics" with a qualitative assessment of attitudes. The actors monitoring focuses only on political entities-individuals 
(politicians/representatives) and subjects (political parties or YPO), again with a qualitative assessment of positive, negative, or neutral type of attitudes. We set the main and partial research question as follows: What forms of strategies are used by YPOs in political communication on the social network Facebook?

1. What are the main frameworks and "hot-topics" in political communication of YPOs on Facebook?

2. What are the main political entities included for political communication of YPOs on Facebook?

Table 2. Data Analysis Approaches. Source: Stieglitz and Dang-Xuan (2012, p. 22).

\begin{tabular}{|c|c|c|c|c|}
\hline \multicolumn{5}{|c|}{ Analysis Purpose } \\
\hline \multicolumn{3}{|c|}{ Reputation \& Impression Management } & \multicolumn{2}{|c|}{ General Monitoring } \\
\hline \multirow{11}{*}{$\begin{array}{l}\text { ANALYSIS } \\
\text { APPROACH }\end{array}$} & \multicolumn{4}{|c|}{ Topic/Issue-Related } \\
\hline & \multirow{2}{*}{$\begin{array}{l}\text { Scanning and monitoring of } \\
\text { topics/issues related to oneself }\end{array}$} & \multirow{2}{*}{$\begin{array}{l}\text { Automated content } \\
\text { analysis }\end{array}$} & $\begin{array}{l}\text { Scanning and monitoring of } \\
\text { topics/issues }\end{array}$ & $\begin{array}{l}\text { Automated content } \\
\text { analysis }\end{array}$ \\
\hline & & & $\begin{array}{l}\text { Prediction of emerging } \\
\text { topics }\end{array}$ & Trend analysis \\
\hline & \multicolumn{4}{|c|}{ Opinion/Sentiment-Related } \\
\hline & \multirow{2}{*}{$\begin{array}{c}\text { Detection of general } \\
\text { perception and prevalent } \\
\text { sentiment associated with } \\
\text { oneself }\end{array}$} & \multirow{2}{*}{$\begin{array}{l}\text { Automated content } \\
\text { analysis/sentiment } \\
\text { analysis }\end{array}$} & $\begin{array}{c}\text { Detection of } \\
\text { opinions/sentiment to } \\
\text { specific topics }\end{array}$ & $\begin{array}{l}\text { Automated content } \\
\text { analysis/sentiment } \\
\text { analysis }\end{array}$ \\
\hline & & & $\begin{array}{l}\text { Identification of emotionally } \\
\text { charged topics }\end{array}$ & $\begin{array}{l}\text { Automated content } \\
\text { analysis/sentiment } \\
\text { analysis }\end{array}$ \\
\hline & \multicolumn{4}{|c|}{ Actor-Related } \\
\hline & \multirow{2}{*}{$\begin{array}{l}\text { Identification of } \\
\text { ideologically/politically } \\
\text { opposed users }\end{array}$} & \multirow{2}{*}{$\begin{array}{l}\text { Automated content } \\
\text { analysis/social network } \\
\text { analysis }\end{array}$} & Identification of lead users & social network analysis \\
\hline & & & $\begin{array}{l}\text { Identification of influential } \\
\text { users/opinion makers }\end{array}$ & social network analysis \\
\hline & \multicolumn{4}{|c|}{ Network-Related } \\
\hline & $\begin{array}{l}\text { Identification of communities } \\
\text { frequenlty mentioning/talking } \\
\text { about oneself }\end{array}$ & Social network analysis & $\begin{array}{l}\text { Detection of politically } \\
\text { relevant communities }\end{array}$ & Social newtork analysis \\
\hline
\end{tabular}

The study compares YPOs at two levels of perspective: national (Slovakia, Czechia) and transnational (YPO of European Political Parties). Selection of the analysed YPOs on both levels takes into account two conditions: active Facebook account of YPO and level of post publishing. For each group the top 6 YPOs are selected. According to selection criteria, included YPOs on the national level have parliamentary and non-parliamentary status. The transnational level is represented by the YPOs of European political parties. The number of cases has limits in the scope of the study. A total of 18 YPOs are identified by following the criteria of selection:

Slovakia: Christian Democratic Youth of Slovakia (Krest'ansko-demokratická mládež Slovenska-KDMS); People's Youth (L'udová Mládež-L’M); Young People Help-We are Family (Mladí pomáhajú-Sme Rodina-MP-SR); Young SaS (Mladí SaSkári-MS); Young Social Democrats (Mladí sociálni demokrati-MSD); and Young for People (Mladí za l'udíMZL),

Czechia: Young Piracy (Mladé Pirátstvo-MP); Young Communists (Mladí komunistéMK); Young People's Party (Mladí lidovci-ML); Young Civic Democrats (Mladí občanskí demokraté-MOD); Young Social Democrats (Mladí sociální demokraté-MSD), Young Mayors and Independents (Mladí starostové a nezávislí-MSaN),

YPOs of European Political Parties: European Liberal Youth (Alliance of Liberal and Democrats for Europe Party); Federation of Young European Greens (The European Greens); Young Democrats for Europe (European Democratic Party/ALDE); Young European Fed- 
eralists; Youth European People's Party (European People's Party); and Young European Socialists (Party of European Socialists).

The study applies The Social Media Analytics Framework (Stieglitz and Dang-Xuan 2012). The study exclusively uses the social network Facebook platform as a data source. Only official Facebook profiles of selected YPOs are monitored. The analysis focuses on the unstructured type of data in the form of "wall-posts". The data tracking approach applies the Random/Explorative strategy. Data are collected manually without the use of Facebook APIs. A separate dataset of wall-posts is created for each YPO. The dataset covers 3-month periods (April, May, and June of 2021). Topic/Issue-Related Approach and Actor-Related Approach are used from Data Analysis Approaches. Two approaches are extended with a self-custom Keyword-Related Approach. Topic/Issue-Related Approach aims to monitor included topics in wall-posts. The Actor-Related Approach focuses on identifying all political support and opposing actors (individuals or organizations/entities). The Keyword-Related Approach seeks to identify the most frequent keywords in wallposts (designated for the top 16 keywords). In the Topic/Issue-Related and Actor-Related Approaches we combine techniques of manual and automatic content analysis. The purpose is to identify the topics and actors as accurately as possible and to know the relationship to them (positive, negative, and neutral). The Keyword-Related Approach uses only the automatic content analysis method. Automated content analysis uses the Text Analysis Tool (Counts Frequencies of Words, Characters, Sentences, and Syllables). Finally a tag clouds with the 10 most frequent keywords are compiled for each group and level-national (Slovakia and Czechia YPO) and supranational (EU perspective). Tag clouds are created by using Voyant Tools.

3. Analysis Results: Facebook Communication of Youth Political Organisations-Cross-Case View (Slovakia, Czechia and European Level)

3.1. Slovakia

Christian Democratic Youth of Slovakia (Krest'ansko-demokratická mládež Slovenska hereinafter referred to as KDMS)

KDMS draws attention to current socio-political events in combination with references to historical memories. The current situation points to the tragic event of former police president's death with a call for a thorough investigation of the event. KDMS adds to the current social events the opportunity to listen to a podcast session on the topic of the census. The purpose is to increase education and awareness of the issue. The COVID-19 pandemic is gaining ground in several dimensions: KDMS primarily seeks to emphasize the verification of media coverage in connection with the pandemic, thus pointing to the frequent occurrence of misinformation. Secondly, it emphasizes adherence to measures to return to the pre-COVID-19 pandemic as soon as possible. A look at history is commemorated by Anton Neuwirth and the 76th anniversary of the liberation of the Auschwitz-Birkenau concentration camp in 1945. It took a positive attitude towards A. Neuwirth as a person with an inspiring story. The memory of the liberation of the concentration camp with a description of tragic events from our region tried to draw attention to avoiding similar situations in the future. Sectoral policy themes focused on the environment. In this case, the post deals with the management of radioactive waste, which arises in the production of electricity in nuclear power plants. KDMS does not take a positive attitude towards the production of electricity in nuclear power plants, it offers an insight into the expert discussion of the topic. We do not find forms of conflict with other subjects or political representatives. The frequency of topics is illustrated in Table 3. 
Table 3. Topics and frequency-KDMS.

\begin{tabular}{cccccc}
\hline Topic & Environment & Census & $\begin{array}{c}\text { Party } \\
\text { Personalities }\end{array}$ & $\begin{array}{c}\text { Historical } \\
\text { Events }\end{array}$ & $\begin{array}{c}\text { Social } \\
\text { Events }\end{array}$ \\
\hline $\begin{array}{c}\text { Frequency } \\
(\mathrm{N}=11)\end{array}$ & 1 & 1 & 1 & 1 & 3 \\
\hline $\begin{array}{c}\text { Percentage } \\
(\% \text { from } \mathrm{N})\end{array}$ & $9 \%$ & $9 \%$ & $9 \%$ & $9 \%$ & $27.5 \%$ \\
\hline
\end{tabular}

Source: author's processing based on posts published on the KDMS Facebook profile (KDMS 2021).

The scope of all published KDMS posts in the monitored period has 3524 characters with 672 words. A lower rate of published posts is indicated by lower keyword occurrences in the post text. The youth identity of the organization in combination with the current social political events is emphasized. The relevant share of interest is demonstrated in connection with historical events. The low share of communication leads to reflection on individual sectoral policy topics. The frequency of keywords is illustrated in Table 4.

Table 4. Keywords in the posts and their frequency-KDMS.

\begin{tabular}{cccccccc}
\hline Keyword & Frequency & Keyword & Frequency & Keyword & Frequency & Keyword & Frequency \\
\hline Young & 4 & Discussion & 3 & Politics & 2 & Concentrat & 2 \\
\hline Foreign & 3 & Slovakia & 2 & Political & 2 & KDMS & 2 \\
\hline Event & 3 & Situation & 2 & Online & 2 & Holocaust & 2 \\
\hline Today & 3 & Friends & 2 & Neuwirth & 2 & Energy & 2 \\
\hline
\end{tabular}

Source: author's processing based on posts published on the KDMS Facebook profile (KDMS 2021).

People's Youth (L'udová Mládež hereinafter referred to as LM)

A key aspect of LM communication is based on the presentation of personalities who are closely connected with Slovak history. The selection takes into account primarily Slovak political actors and artists who have contributed to active work for the benefit of the Slovak national consciousness. The period under review offers a brief biographical description of the most important activities of Jozef Miloslav Hurban, Samo Chalupka, Jozef Murgaš, Karol Holuby, or Samo Tomášik. Their deserving activities for the benefit of the Slovak nation and the rights of the Slovak nation are emphasized, which shows the organization's proximity to national identity. The second important area of LM communication deals with the COVID-19 pandemic situation. In this case, on the contrary, a negative attitude is expressed towards the measures that are implemented through the current Government of the Slovak Republic and its ministries. The high financial costs of operating COVID-19 testing platforms or the established state of emergency are exposed to criticism. In addition to historical figures and the current pandemic situation, the LM also comments on the situation on the Slovak national scene. Once again, aspects of criticism of other entities appear, which in political activities present mainly national identity. The frequency of topics is illustrated in Table 5.

Table 5. Topics and frequency-LM.

\begin{tabular}{ccccc}
\hline Topic & $\begin{array}{c}\text { Personalities of } \\
\text { Slovak History }\end{array}$ & COVID19 & $\begin{array}{c}\text { The Quality } \\
\text { of Democracy }\end{array}$ & Other \\
\hline Frequency $(\mathrm{N}=10)$ & 6 & 2 & 1 & 1 \\
\hline Percentage $(\%$ from $\mathrm{N})$ & $60 \%$ & $20 \%$ & $10 \%$ & $10 \%$ \\
\hline Source: author's processing based on posts published on the LM Facebook profile (LM 2021).
\end{tabular}

There are posts dedicated to Slovak national historians, artists, and scientists. The element of Slovak national identity dominates in a total of 8992 characters and 1782 words. 
There is a positive affection for the Slovak national consciousness, which is complemented by criticism of current political entities on the national scene, who could potentially form political partners. Depending on the presence of keywords, a negative emphasis is also applied to current solutions of the COVID-19 pandemic situation. At the same time, they are linked to the government's criticism. The frequency of keywords is illustrated in Table 6.

Table 6. Keywords in the posts and their frequency-LM.

\begin{tabular}{ccccccccc}
\hline Keyword & Frequency & Keyword & Frequency & Keyword & Frequency & Keyword & Frequency \\
\hline Slovakian & 13 & Years & 6 & freedom & 4 & Tatra & 3 \\
\hline Slovak & 11 & Hurban & 5 & testing & 4 & Slovakia & 3 \\
\hline eur & 11 & Chalupka & 5 & Murgaš & 4 & fighter & 3 \\
\hline year & 9 & death & 4 & voluntee & 4 & Vajanský & 2 \\
\hline
\end{tabular}

Source: author's processing based on posts published on the LM Facebook profile (LM 2021).

Young people help-We are family (Mladí pomáhajú-Sme rodina hereinafter referred to as MP-SR)

We find the first open criticism in political communication towards specific political opponents in the MP-SR. It is directed against Hlas-SD representative Peter Pellegrini on the issue of using a state plane to travel abroad. The solution of sectoral issues is focused on food and transport policy and animal protection while the letter is becoming the most published of its kind. In addition to legislative activities in the parliament of the parent party We Are Family, the activities of members of the organization in the field are presented. Attention is once again focused on proposals for legislative changes in transport policy proposed by the parent party. The COVID-19 pandemic communication is present through the presentation of activities aimed at helping to mitigate its negative effects. The frequency of topics is illustrated in Table 7.

Table 7. Topics and frequency-MP-SR.

\begin{tabular}{|c|c|c|c|c|c|c|}
\hline Topic & COVID-19 & $\begin{array}{c}\text { Animal } \\
\text { Protection }\end{array}$ & $\begin{array}{c}\text { Political } \\
\text { Opponents }\end{array}$ & $\begin{array}{l}\text { Food } \\
\text { Policy }\end{array}$ & $\begin{array}{c}\text { Transport } \\
\text { Policy }\end{array}$ & $\begin{array}{c}\text { Party } \\
\text { Leaders }\end{array}$ \\
\hline $\begin{array}{l}\text { Frequency } \\
\quad(\mathrm{N}=8)\end{array}$ & 1 & 3 & 1 & 1 & 1 & 1 \\
\hline $\begin{array}{c}\text { Percentage } \\
\text { (from N) }\end{array}$ & $12.5 \%$ & $37.5 \%$ & $12.5 \%$ & $12.5 \%$ & $12.5 \%$ & $12.5 \%$ \\
\hline
\end{tabular}

Character and word counts reach similar values as the KDMS organization. At the forefront of the occurrence of keywords is the draft legislative changes to the Road Act. Elements of assistance and protection are highlighted, to which the MP-SR draws attention. There is also a positive attitude towards the care of citizens, which points to the presence of a social perception of society's problems. The frequency of keywords is illustrated in Table 8 .

Table 8. Keywords in posts and their frequency-MP-SR.

\begin{tabular}{cccccccc}
\hline Keyword & Frequency & Keyword & Frequency & Keyword & Frequency & Keyword & Frequency \\
\hline vehicle & 12 & security & 3 & help & 3 & via & 2 \\
\hline animals & 8 & money & 3 & protect & 3 & proces & 2 \\
\hline table & 4 & system & 3 & evidence & 3 & problem & 2 \\
\hline legislation & 4 & care & 3 & group & 2 & Family & 2 \\
\hline & & Source: author's processing based on posts published on the MP-SR Facebook profile (MP-SR 2021).
\end{tabular}


Young SaS (Mladí SaSkári hereinafter referred to as MS)

MS communication is concentrated on three basic lines. The first line is set up to communicate with political partners or opponents, and the second line is linked to responses to sectoral policies and current socio-political events. The third line presents activities focused on the activities of the organization, the parent political party and its representatives, and cooperation with other youth organizations. The MS has two antagonistic forms of communication towards the political partners at the level of the parent political parties, which are currently cooperating in the coalition. Despite the fact that it is a coalition partner, critical and negative contributions are directed towards selected OL'aNO representatives. On the other hand, we record support contributions to the representatives of Za l'udí, taking into account the consensus and political agreement of the partners. Against political opponents from the ranks of the opposition, the activity is escalating primarily towards Smer-SD and Hlas-SD. In addition to active communication with the main political parties, active communication also appears towards other youth political organizations. They take negative advantage especially against the Young Social Democrats and the person of Livia Garčalová from Kulturblog. We do not record negative contributions to other youth political organizations. MS together with Mladí za l'udí and Mladí progresívci present active cooperation. In given cases, we identify joint implementation of discussions or support in legislative activities in the parliament. The current socio-political events reflect primarily on the situation and events surrounding the COVID-19 pandemic and political measures. The historical context commemorates the day of the Holocaust victims. An interesting aspect arises in the case of ideological conflict against left-wing representatives defending socialism. The conflicting line is also manifested in the case of the census, specifically MS reacts against the churches. The issue of decriminalization of marijuana is gaining an important place from the program point of view of the parent party SaS, while the position of the MS copies the positive attitudes of the parent party towards decriminalization. The frequency of topics is illustrated in Table 9.

Table 9. Topics and frequency-MS.

\begin{tabular}{|c|c|c|c|c|c|c|c|}
\hline Topic & School & $\begin{array}{l}\text { Historical } \\
\text { Events }\end{array}$ & Coalition Parties & Social Events & $\begin{array}{c}\text { Political } \\
\text { Opponents }\end{array}$ & Census & $\begin{array}{l}\text { Party } \\
\text { Leaders }\end{array}$ \\
\hline $\begin{array}{l}\text { Frequency } \\
(\mathrm{N}=53)\end{array}$ & 1 & 2 & 11 & 4 & 7 & 1 & 2 \\
\hline $\begin{array}{l}\text { Percentage } \\
(\% \text { from N) }\end{array}$ & $1.9 \%$ & $3.8 \%$ & $20.4 \%$ & $7.6 \%$ & $13.2 \%$ & $1.9 \%$ & $3.8 \%$ \\
\hline Topic & COVID-19 & Economy & $\begin{array}{l}\text { Youth Political } \\
\text { Organizations }\end{array}$ & $\begin{array}{c}\text { Decriminalization } \\
\text { of Marijuana }\end{array}$ & Disinformation & $\begin{array}{c}\text { Organization } \\
\text { Activities }\end{array}$ & Environment \\
\hline $\begin{array}{l}\text { Frequency } \\
\quad(\mathrm{N}=53)\end{array}$ & 10 & 1 & 4 & 1 & 1 & 4 & 4 \\
\hline $\begin{array}{l}\text { Percentage } \\
(\% \text { from N) }\end{array}$ & $18.9 \%$ & $1.9 \%$ & $7.6 \%$ & $1.9 \%$ & $1.9 \%$ & $7.6 \%$ & $7.6 \%$ \\
\hline
\end{tabular}

Source: author's processing based on contributions published on the MS profile on Facebook (MS 2021).

The number of 19,490 characters in 3858 words represents, among all monitored Slovak youth political organizations, the highest quality of posts. These tend to highlight the organization's own identity and its youthful nature. The creation of conflict lines of an ideological nature or towards other operating institutions, whether of a political or social nature, comes to the fore. Significant social events and reflections on the COVID19 pandemic are also communicated. Aspects of setting up measures, using data, and informing the public are highlighted. The frequency of keywords is illustrated in Table 10. 
Table 10. Keywords in posts and their frequency-MS.

\begin{tabular}{cccccccc}
\hline Keyword & Frequency & Keyword & Frequency & Keyword & Frequency & Keyword & Frequency \\
\hline Young & 15 & SaSkar & 7 & inform & 6 & church \\
\hline Society & 11 & Hlas & 7 & Health & 5 & transparent & 4 \\
\hline Testing & 7 & High & 6 & Test & 5 & freedom & 4 \\
\hline party & 7 & Richard & 6 & attitude & 5 & Smer \\
\hline
\end{tabular}

Source: author's processing based on posts published on the MS Facebook profile (MS 2021).

Young Social Democrats (Mladí sociálni demokrati hereinafter referred to as MSD-SR)

The most common phenomenon in MSD-SR communication is the confrontation with various political opponents. The active form of criticism is directed against the political parties that form the current coalition-OL'ANO, Za l'udí, and SaS. Sme rodina is disconnected from communication at a given time period. While MS actively communicates criticism through their contributions to MSD-SR, MSD-SR does not direct any contributions to MS and focuses exclusively on major political parties. The youth accent is manifested only in the form of presentation of its own activities. The current socio-political events are primarily oriented around two areas-the COVID-19 pandemic and the referendum for the end of the current election period. In both cases, the communication has the character of a critique of the current government. The opposition and criticism of the COVID-19 pandemic situation, highlighted by the requirement to end the current parliamentary term through a referendum, is highlighted. The ideological counterbalance manifests itself in the case of the approved security strategy of the Slovak Republic. According to MSDSR, the adopted security strategy has an imbalance and orientation exclusively to NATO organizations. The ideological element of the left-wing character of MSD-SR is found by highlighting the World Day of Social Justice. The frequency of topics is illustrated in Table 11.

Table 11. Topics and Frequency-MSD-SR.

\begin{tabular}{|c|c|c|c|c|c|c|c|c|}
\hline Topic & $\begin{array}{c}\text { Party } \\
\text { Leaders }\end{array}$ & $\begin{array}{c}\text { Political } \\
\text { Opponents }\end{array}$ & $\begin{array}{l}\text { Social } \\
\text { Policy }\end{array}$ & COVID-19 & Referendum & School & $\begin{array}{l}\text { Political } \\
\text { Partners }\end{array}$ & $\begin{array}{l}\text { Social } \\
\text { Events }\end{array}$ \\
\hline $\begin{array}{l}\text { Frequency } \\
(\mathrm{N}=23)\end{array}$ & 2 & 6 & 1 & 4 & 3 & 1 & 1 & 2 \\
\hline $\begin{array}{l}\text { Percentage } \\
(\% \text { from N) }\end{array}$ & $8.3 \%$ & $27.2 \%$ & $4.3 \%$ & $17.4 \%$ & $13 \%$ & $4.3 \%$ & $4.3 \%$ & $8.3 \%$ \\
\hline Topic & $\begin{array}{c}\text { MSD } \\
\text { Activities }\end{array}$ & $\begin{array}{l}\text { Security } \\
\text { Policy }\end{array}$ & $\begin{array}{l}\text { Prosecutor's } \\
\text { Office }\end{array}$ & & & & & \\
\hline $\begin{array}{c}\text { Frequency } \\
(\mathrm{N}=23)\end{array}$ & 1 & 1 & 1 & & & & & \\
\hline $\begin{array}{l}\text { Percentage } \\
(\% \text { from N) }\end{array}$ & $4.3 \%$ & $4.3 \%$ & $4.3 \%$ & & & & & \\
\hline
\end{tabular}

Source: author's processing based on posts published on a MSD-SD Facebook profile (MSD-SR 2021).

There are 14,030 characters and 2584 words, which ranks MSD-SR second in the context of the qualitative range of posts. Criticism of the coalition is becoming an essential goal of communication. The person Igor Matovič has become the most significant target of criticism. The negative manifestations of communication from the youth organization MS towards MSD-SR remain unanswered. The MSD-SR focuses exclusively on the environment of major political parties, with youth organizations being ignored. The typical left-wing ideological characteristics of the MSD-SR take concrete form when highlighting the topic of social justice. The frequency of keywords is illustrated in Table 12. 
Table 12. Keywords in posts and their frequency-MSD-SR.

\begin{tabular}{cccccccc}
\hline Keyword & Frequency & Keyword & Frequency & Keyword & Frequency & Keyword & Frequency \\
\hline Matovič & 9 & Public & 6 & Smer & 4 & secure \\
\hline politics & 8 & Igor & 6 & Slovakia & 4 & Health & 3 \\
\hline Monika & 7 & Event & 5 & family & 4 & justice & 3 \\
\hline candidate & 7 & justice & 5 & prosecutor & 4 & referendum & 3 \\
\hline & & Source: author's processing based on posts published on the MSD-SR Facebook profile (MSD-SR 2021).
\end{tabular}

Source: author's processing based on posts published on the MSD-SR Facebook profile (MSD-SR 2021).

Young For People (Mladí Za l'udí hereinafter referred to as MZL)

MZL perceives the purchase of SPUTNIK V vaccine as problematic, while the conflict with the coalition partner OL'aNO and the person of Igor Matovič as well as Eurofunds also with the SaS party came to the front. The thematic approach to the COVID-19 pandemic is dedicated exclusively to SPUTNIK V vaccine. From the current opposition political parties, Smer-SD and Hlas-SD appear in the conflict line of MZL. Current socio-political events focus on two events. The first is criticism of Hlas-SD and Smer-SD, which are seeking a referendum for the early end of the current parliamentary term. The second important communication element points to the census. They consider the possibility of choosing two nationalities for the population as important. The aspect of strict national perception with the designation of a single nationality is criticized. The attitude of MZL reflects the parent party Za l'udí, which proposes to expand the identification of the citizen in society in a greater choice of two preferences in the question of nationality. The frequency of topics is illustrated in Table 13.

Table 13. Topics and frequency-MZL'.

\begin{tabular}{cccccccc}
\hline Topic & COVID-19 & $\begin{array}{c}\text { Coalition } \\
\text { Partners }\end{array}$ & Census & Referendum & $\begin{array}{c}\text { Political } \\
\text { Opponents }\end{array}$ & $\begin{array}{c}\text { Election } \\
\text { Survey }\end{array}$ & $\begin{array}{c}\text { Party } \\
\text { Leaders }\end{array}$ \\
\hline $\begin{array}{c}\text { Frequency } \\
(\mathrm{N}=15)\end{array}$ & 3 & 2 & 1 & 1 & 5 & 1 & 2 \\
\hline $\begin{array}{c}\text { Percentage } \\
(\% \text { from N) }\end{array}$ & $20 \%$ & $13.3 \%$ & $6.7 \%$ & $6.7 \%$ & $33.3 \%$ & $6.7 \%$ & $13.3 \%$ \\
\hline
\end{tabular}

Source: author's processing based on contributions published on the MZL Facebook profile (MZL 2021).

Resolving the COVID-19 pandemic situation and conflict situations with political opponents are becoming essential goals of MZL communication. In 6573 characters and 1200 words, we find MZL argues against the purchase of SPUTNIK V vaccines and the holding of a referendum for the early termination of the current election period. Intensive communication is directed towards Peter Pellegrini and Igor Matovič. Despite the different positions of both representatives in parliament, they are exclusively criticized. The frequency of keywords is illustrated in Table 14.

Table 14. Keywords in posts and their frequency-MZL.

\begin{tabular}{ccccccccc}
\hline Keyword & Frequency & Keyword & Frequency & Keyword & Frequency & Keyword & Frequency \\
\hline Hlas & 8 & except & 6 & responsible & 3 & Petra & 3 \\
\hline vaccine & 7 & party & 5 & Sputnik & 3 & people & 3 \\
\hline Peter & 7 & society & 5 & Smer & 3 & minister & 3 \\
\hline eur & 7 & inform & 4 & PM & 3 & negotiation & 3 \\
\hline
\end{tabular}

Source: author's processing based on contributions published on the MZL Facebook profile (MZL 2021).

Evaluation of Political Communication of Slovak Youth Political Organizations 
In the Facebook communication of Slovak youth political organizations, we identify several basic categories of posts. The first group deals with political topics where selected aspects of the environment, food policy, transport policy, or social policy are discussed. Attention is also focused on specific areas related to the decriminalization of marijuana or the census. The second group includes various forms of conflict or supportive attitudes towards other entities (major political parties in the party system; youth political organizations) or political representatives. Conflicts are transferred from the environment of the parent political parties unchanged to the level of youth political organizations. There are entities that act towards each other or are mutually supportive. A similar scenario continues with criticism of selected political leaders. In addition to the expected conflict line, the coalition (MZL, MS) vs. opposition (MSD-SR) also record critical attitudes among organizations whose parties are coalition partners. The overall character of the conflict lines is complemented by the traditional battles on the left axis (MSD-SR) vs. right (MZL), or Social Democracy (MSD-SR)-Liberalism (MS) and Nationalism (LM). The third set of posts present important personalities who are currently or have been members of the parent party in the past, or are presented by the organization, for example, in an ideological and programmatic connection. At the end, we add a separate main group of communicated posts related to COVID-19 pandemic. Various approaches are identified, the aim of which is to criticize, educate, or increase the awareness of the population. Critical attitudes draw attention to the forms of measures taken by the current government with an emphasis on the financial burden from the Slovak budget. Published posts in this case do not show signs of misinformation that would deny the fact or existence of a pandemic that would possibly alleviate the situation. The purpose is to take a critical and conflicting position vis-à-vis the current government. Within the second perspective of COVID-19 posts, we find efforts to increase the level of education and awareness. The primary emphasis is on changing citizens' attitudes towards vaccination and strict adherence to current measures. The most frequent keywords in the posts of Slovak youth political organisations are illustrated in Figure 1.

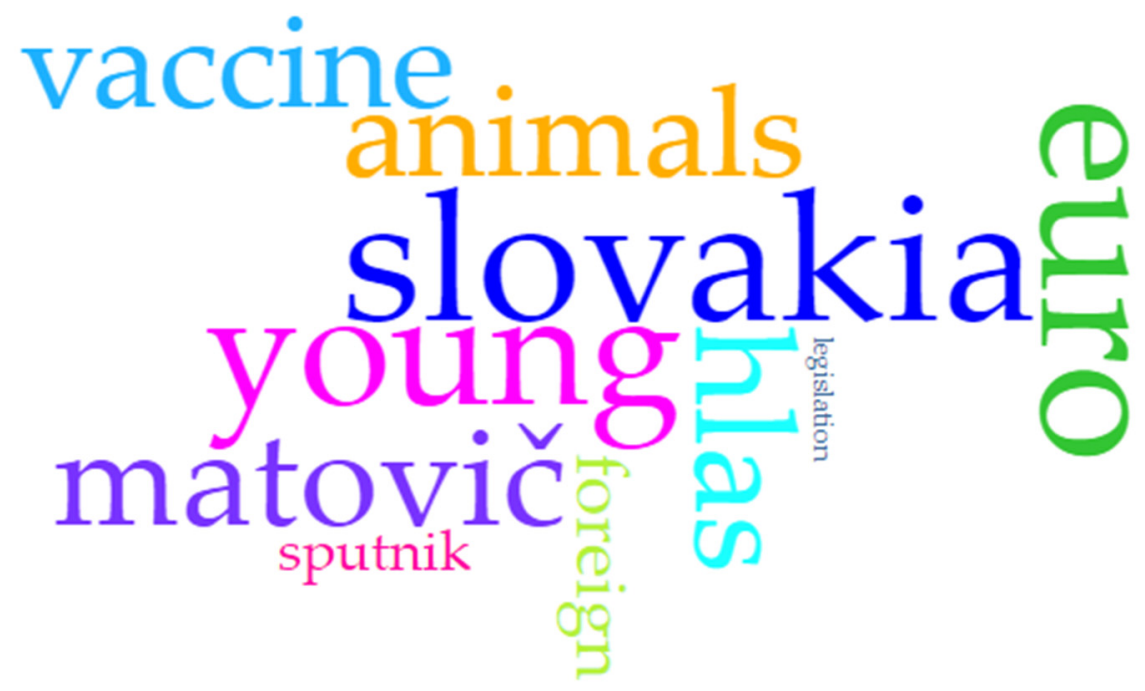

Figure 1. The most frequent keywords in the posts of Slovak youth political organizations. Source: author's processing on the basis of posts published on Facebook profiles (MZL 2021; MSD-SR 2021; MS 2021; MP-SR 2021; LM 2021; KDMS 2021).

\subsection{Czechia}

Young Piracy (Mladé Pirátstvo Hereinafter Referred to as MP)

A look at MP communication identifies the most significant focus on electoral issues. Three separate aspects are apparent in this regard. The first concerns the current setting of the electoral system for the Chamber of Deputies of the Czech Republic. The MP takes a 
positive stance on the decision of the Constitutional Court of the Czech Republic on the unconstitutionality of the electoral system; on the other hand, it perceives the complexity of negotiations that will lead to a new setting of elections to the Chamber of Deputies of the Czech Republic. The issue of elections continues with the presentation of pre-election negotiations with the STAN party, with which it managed to successfully conclude electoral coalition cooperation. The last aspect is the communication of the published pre-election survey to the preferences of political parties. The MP does not communicate specific topics, but does affect the COVID-19 pandemic. In this case, the communication is set up to explain the introduction of an emergency. It does not take a positive or negative position towards the state of emergency, on the contrary, it seeks a detailed explanation of the conditions for declaring a state of emergency, the duration, and the possibilities that the state of emergency allows the government. The purpose is the informative and educational value of the post. The frequency of topics is illustrated in Table 15.

Table 15. Topics and frequency-MP.

\begin{tabular}{ccccccc}
\hline Topic & $\begin{array}{c}\text { Party } \\
\text { Events }\end{array}$ & $\begin{array}{c}\text { Election } \\
\text { Survey }\end{array}$ & COVID-19 & $\begin{array}{c}\text { Electoral } \\
\text { System }\end{array}$ & $\begin{array}{c}\text { Political } \\
\text { Partners }\end{array}$ & $\begin{array}{c}\text { Organization } \\
\text { Events }\end{array}$ \\
\hline $\begin{array}{c}\text { Frequency } \\
(\mathrm{N}=10)\end{array}$ & 2 & 1 & 2 & 1 & 2 & 2 \\
\hline $\begin{array}{l}\text { Percentage } \\
(\% \text { from N) }\end{array}$ & $20 \%$ & $10 \%$ & $20 \%$ & $10 \%$ & $20 \%$ & $20 \%$ \\
\hline Source: author's processing based on posts published on the MP's Facebook profile (MP 2021).
\end{tabular}

The MP places the most emphasis on its own youth identity in connection with the electoral and pre-election issues. The use of various online platforms is gaining ground, replacing face-to-face meetings and negotiations during the COVID-19 pandemic. The Twitch streaming platform is becoming a temporary home for MP. The presentation of the joint coalition with the partner STAN has a positive effect. We identify the educational nature in case of explaining the established state of emergency with consequences for society. Total communicated posts contain 2945 characters and 587 words. The frequency of keywords is illustrated in Table 16.

Table 16. Keywords in posts and their frequency-MP.

\begin{tabular}{cccccccc}
\hline Keyword & Frequency & Keyword & Frequency & Keyword & Frequency & Keyword & Frequency \\
\hline Young & 6 & electoral & 3 & mStan & 3 & Coalition & 2 \\
\hline Election & 5 & twitch & 3 & streaming & 2 & activity & 2 \\
\hline Society & 4 & www & 3 & cooperation & 2 & Emergency & 2 \\
\hline Youngpirat & 4 & https & 3 & system & 2 & parliament \\
\hline
\end{tabular}

Source: author's processing based on posts published on the MP's Facebook profile (MP 2021).

Young Communists KSČM (Mladí komunisté Hereinafter Referred to as MK)

The Communist Manifesto and the victorious February 1948 form the basic framework for the presentation of the MK's ideological grasp. Alongside is a critique of capitalism, which completes the traditional conflict between communism and capitalism. To protect the interests of workers, MK emphasizes the work of trade unions. By organizing in trade unions, the MK sees a solution to how workers can actively solve work problems. The international character manifests itself in the form of the support of the young Spanish communist Pablo Hasel, who was convicted of insulting the monarchy and supporting terrorism. The MK joins the collective support of communist youth organizations affiliated with The El Youth Network, who are demanding the release of young communist. Current socio-political developments are only becoming known through the COVID-19 pandemic. 
The issue of health comes to the fore as a matter of public affairs. In other respects, COVID19 is not addressed without a positive or negative attitude. The remaining part of the MK communication is filled mainly by the organization's activities. Members of MK who were successful in placing the candidate lists of the parent KSČM in the elections to the Chamber of Deputies of the Czech Republic are highlighted. The frequency of topics is illustrated in Table 17.

Table 17. Topics and Frequency-MK.

\begin{tabular}{|c|c|c|c|c|c|c|c|}
\hline Topic & $\begin{array}{l}\text { Organization } \\
\text { Activities }\end{array}$ & $\begin{array}{c}\text { European Youth } \\
\text { Political Organization }\end{array}$ & $\begin{array}{l}\text { Historical } \\
\text { Events }\end{array}$ & COVID-19 & $\begin{array}{l}\text { Trade } \\
\text { Unions }\end{array}$ & Economy & Ideology \\
\hline $\begin{array}{l}\text { Frequency } \\
(\mathrm{N}=13)\end{array}$ & 5 & 1 & 2 & 1 & 1 & 1 & 2 \\
\hline $\begin{array}{l}\text { Percentage } \\
(\% \text { from N) }\end{array}$ & $38.4 \%$ & $7.7 \%$ & $15.4 \%$ & $7.7 \%$ & $7.7 \%$ & $7.7 \%$ & $15.4 \%$ \\
\hline
\end{tabular}

Source: author's processing based on contributions published on the MK Facebook profile (MK 2021).

The frequency of publishing posts and their qualitative range does not have a high frequency of characters or words (2211 characters, 415 words). According to the keywords, the youthful nature of the organization and the ideological concept of communism, which is based on the name of the organization, are emphasized primarily. The Communist Manifesto, the victorious February 1948, and the trade unions became essential identifiers. International cooperation with other youth communist organizations at the transnational level is also added. Depending on the occurrence and number of keywords, the symbolism of the organization is also strengthened through the communication of color and the traditional logo of communist organizations. The frequency of keywords is illustrated in Table 18.

Table 18. Keywords in posts and their frequency-MK.

\begin{tabular}{cccccccc}
\hline Keyword & Frequency & Keyword & Frequency & Keyword & Frequency & Keyword & Frequency \\
\hline young & 9 & election & 3 & Organization & 2 & initiative & 2 \\
\hline communist & 6 & candidate & 3 & Network & 2 & photo & 2 \\
\hline support & 3 & youth & 2 & Region & 2 & president & 2 \\
\hline manifest & 3 & red & 2 & communists & 2 & days & 2 \\
\hline
\end{tabular}

Source: author's processing based on posts published on the MC's Facebook profile (MK 2021).

Young People's Party (Mladí lidovci Hereinafter Referred to as ML)

Encyclical Fratelli Tutti, authored by Jorge Mario Bergoglio, also known as Pope Francis, plays a central role in ML communications. Posts do not focus on the content analysis of the encyclical. They offer information on holding debates with guests who discuss the encyclical. Users have the opportunity to interact directly and participate in the discussion through comments below the posts. As in the case of the MK, the ML also commemorates the anniversary of February 1948. In case of the ML, unlike the MK, who perceive February 1948 as a victory, we find a contradictory attitude in the form of a coup. They also complement the period of communism with the 52nd anniversary of the burning of Ján Palach, who draws attention to the negative aspects of the communist-led regime. Historical events are completed by the memory of the Holocaust Remembrance Day. In addition to drawing attention to the negative manifestations of the communist regime, there is also a reflection on the actions of the Nazi regime. The COVID-19 pandemic, after ideological elements, represents the second key issue of ML communication. First of all, the ML expresses their gratitude for the solidarity and help they have shown from foreign partners. The post also earned translations into German and English, which we have not recorded in the analysis so far. The impact of the coronavirus also negatively affected the 
activities of the organization itself. As a consequence, restrictions on ML members' foreign trips to meetings with other partner youth organizations are mentioned. Cross-border cooperation and support from partners abroad are gaining attention in the election of the new chairman of the German political party CDU, Armin Laschet. The remaining part of the contributions is devoted to the activities of the youth organization itself and the activities of the parent party KDU. The achievements of ML members who have successfully obtained a place on the list of candidates for the elections to the Chamber of Deputies of the Czech Republic or obtained the positions of mayor at the local government level are highlighted. The frequency of topics is illustrated in Table 19.

Table 19. Topics and Frequency-ML.

\begin{tabular}{ccccccc}
\hline Topic & $\begin{array}{c}\text { Encyclical } \\
\text { Fratelli Tutti }\end{array}$ & $\begin{array}{c}\text { Historical } \\
\text { Events }\end{array}$ & $\begin{array}{c}\text { Party } \\
\text { Activities }\end{array}$ & COVID-19 & $\begin{array}{c}\text { Organization } \\
\text { Activities }\end{array}$ & $\begin{array}{c}\text { Electoral } \\
\text { System }\end{array}$ \\
\hline $\begin{array}{c}\text { Frequency } \\
(\mathrm{N}=21)\end{array}$ & 4 & 4 & 2 & 3 & 5 & 1 \\
\hline $\begin{array}{c}\text { Peaders } \\
\text { Percentage }\end{array}$ & $19 \%$ & $19 \%$ & $9.5 \%$ & $14.3 \%$ & $23.8 \%$ & 1 \\
\hline
\end{tabular}

Source: author's processing based on posts published on the ML Facebook profile (ML 2021).

The total of 4847 characters and 906 words determines approximately twice the number of quantitative indicators of the scope of posts than in the case of MK. According to the number of keywords, the youth identity of the organization is most pronounced. Important topics are represented by historical events related to the previous political regimes. The ideological essence of the ML organization can be combined with the active presentation of the encyclical Fratelli Tutti. The negative effects of the COVID-19 pandemic have led to the relocation of activities to the online space. The achievements of ML members are given a relevant place, as well as the gratitude for showing solidarity and help from foreign partners and states. The frequency of keywords is illustrated in Table 20.

Table 20. Keywords in posts and their frequency-ML.

\begin{tabular}{cccccccc}
\hline Keyword & Frequency & Keyword & Frequency & Keyword & Frequency & Keyword & Frequency \\
\hline Young & 7 & Fratelli & 4 & https & 3 & Mayor & 2 \\
\hline Problems & 6 & Meet & 3 & www & 3 & solidarity & 2 \\
\hline Today & 6 & Pandemic & 3 & Memory & 2 & Follow & 2 \\
\hline Tutti & 4 & online & 3 & Republic & 2 & Young people's & 2 \\
\hline
\end{tabular}

Source: author's processing based on posts published on the ML Facebook profile (ML 2021).

Young Civic Democrats (Mladí Občanskí Demokraté Hereinafter Referred to as MOD)

MOD focuses communication exclusively on current political events. The most important space is gained by holding elections to the Chamber of Deputies in the Czech Republic. Brief contributions try to mobilize voters to support the candidates of the ODS political party where MOD also lists its young candidates. The interaction of supporters and the public with MOD and ODS representatives is ensured by online streaming with the possibility to ask questions. We do not register solutions to political issues, other current socio-political problems, historical events, or the COVID-19 pandemic. The exception in MOD very brief communication is supplemented by a reference to a podcast with the MOD coordinator. The central theme of the podcast discusses the functioning of a political party and ways to engage in politics at the municipal level. The frequency of topics is illustrated in Table 21. 
Table 21. Topics and frequency-MOD.

\begin{tabular}{cccc}
\hline Topic & Party Leaders & Campaign & Organization Activities \\
\hline Frequency $(\mathrm{N}=4)$ & 1 & 2 & 1 \\
\hline Percentage $(\%$ from $\mathrm{N})$ & $25 \%$ & $50 \%$ & $25 \%$ \\
\hline Source: author's processing based on posts published on the MOD profile on Facebook (MOD 2021).
\end{tabular}

MOD is presented with a relatively low frequency of published posts in conjunction with a brief content of 556 characters and 114 words. Elections to the Chamber of Deputies of the Czech Republic are the only key and most important element of MOD communication. In addition to the low level of interest in current socio-political events or sectoral issues, we find only a focus on our own subject and the parent political party. The organization presents its own profile without conflict or criticism to competitors. The frequency of keywords is illustrated in Table 22.

Table 22. Keywords in posts and their frequency-MOD.

\begin{tabular}{cccccccc}
\hline Keyword & Frequency & Keyword & Frequency & Keyword & Frequency & Keyword & Frequency \\
\hline engage & 1 & Party & 1 & listen & 1 & Podcast & 1 \\
\hline election & 1 & Saturday & 1 & Politics & 1 & Answer & 1 \\
\hline interest & 1 & object & 1 & Policy & 1 & Communicaion & 1 \\
\hline subject & 1 & Praha & 1 & Support & 1 & Candidate & 1 \\
\hline
\end{tabular}

Source: author's processing based on posts published on the MOD profile on Facebook (MOD 2021).

Young Social Democrats (Mladí Sociální Demokraté Hereinafter Reffered to as MSDCR)

The central themes of MSD-CR in political communication represent the economy and health care in connection with the COVID-19 pandemic. While in previous cases of Czech youth political organizations, the discussion of sectoral topics has come to the margins, MSD-CR, on the other hand, is bringing this area to the forefront. From the point of view of time, as the most recent topic (date of publication 20 February 2021) we identify a negative perception of the proposal of gradual opening of shops, which according to MSD-CR may cause a consequent increase in the risk of spreading the disease. It thus argues the possibility of negative effects on the operation of the health care system. The need for patience and adherence to measures is recalled. The dimension of the economy is complemented by criticisms of the proposed changes in the tax area. The purpose of the post is to highlight the five most important risks of the tax reform, which is being prepared by political opponents from ANO, SPD, and ODS parties. Daniela Ostrá, the vice-president of MSD-CR, comments on the youth policy in an interesting way. From her point of view, youth policy is a place where it has the opportunity to be louder, sharper, more radical, and publicly claim rights. In addition to previous cases of criticism or conflict, this is the first realistic expression highlighting the possibility of a more radical emphasis in the environment of youth policy. From the point of view of the MSD-CR, the range of communicated topics ends in the monitored period. It does not touch on any other current socio-political topics, does not reflect on historical events, and does not emphasize the ideological elements of the organization or the parent party CSSD. The frequency of topics is illustrated in Table 23. 
Table 23. Topics and frequency-MSD-CR.

\begin{tabular}{cccc}
\hline Topic & COVID19 & Organization Activities & Economy \\
\hline Frequency $(\mathrm{N}=3)$ & 1 & 1 & 1 \\
\hline Percentage $(\%$ from $\mathrm{N})$ & $33.3 \%$ & $33.3 \%$ & $33.3 \%$ \\
\hline Source: author's processing based on posts published on the MSD Facebook profile (MSD-CR 2021).
\end{tabular}

The occurrence of 892 characters in 167 words brings MSD-CR close to MOD. The organization is not characterized by a high frequency of posts publication, which is reflected in the range of topics communicated. It focuses primarily on the health and economic sectors in connection with COVID-19. ANO, SPD, and ODS parties are being criticized. MSD-CR Vice-President Daniela Ostrá describes the environment of youth policy and the opportunity to more radically claim its rights in its area. The frequency of keywords is illustrated in Table 24.

Table 24. Keywords in posts and their frequency-MSD-CR.

\begin{tabular}{cccccccc}
\hline Keyword & Frequency & Keyword & Frequency & Keyword & Frequency & Keyword & Frequency \\
\hline health & 2 & superminister & 1 & SPD & 1 & risk & 1 \\
\hline reform & 2 & student & 1 & sum & 1 & risks & 1 \\
\hline evoke & 1 & Speculate & 1 & interview & 1 & radical & 1 \\
\hline sleep & 1 & Situation & 1 & decide & 1 & program & 1 \\
\hline
\end{tabular}

Source: author's processing based on posts published on the MSD-CR Facebook profile (MSD-CR 2021).

Mladí Starostové a Nezávislí (Mladí Starostové A Nezávislí Hereinafter Referred to as MSaN)

The core of MSaN communication is to manage the COVID-19 pandemic. The posts refer to various problems and situations that the pandemic brings. MSaN criticizes the government's approach to declaring a state of emergency. In addition, the informationeducational value of the posts comes to the fore with the topic of COVID-19. The content offers, for example, information about the respondent's experience with traveling abroad, or a description of how the coronavirus mutates with emphasis on the nature of vaccination. MSaN also connects COVID-19 with its impact on the environment. In this case, data are available, for example, on reducing the smog situation in the regions of the Czech Republic. As in the case of the MP, the relevant coalition cooperation with the aforementioned partner gains a relevant place. Both entities have a common interest in changing the electoral system to the Chamber of Deputies of the Czech Republic. Together, they positively welcome the decision of the Constitutional Court of the Czech Republic, which annulled some parts of the law concerning the regulation of elections. They agree similarly on the presentation of electoral support surveys, which are currently favorable to MSaN and MP. They also extend the issue of legislative power in the Czech Republic by learning about the legislative process. Users are offered the opportunity to monitor current legislative activity through the eKLEP application for the public. MSaN is also active in discussing various political topics. In foreign policy, they focus on the US presidential election or the arrest and imprisonment of Alexei Navalny in Russia. Joe Biden's victory in the US presidential election is perceived positively, while A. Navalny's imprisonment in Russia is perceived negatively. The topics of dual food quality, the pension system, and social policy gain a partial place in communication. The overall published content is completed by information about the organization's activities or criticism of political opponents. The frequency of topics is illustrated in Table 25. 
Table 25. Topics and frequency-MSaN.

\begin{tabular}{|c|c|c|c|c|c|c|c|c|}
\hline Topic & $\begin{array}{l}\text { Social } \\
\text { Policy }\end{array}$ & $\begin{array}{c}\text { Organization } \\
\text { Activities }\end{array}$ & Environment & $\begin{array}{l}\text { Legislation } \\
\text { Process }\end{array}$ & COVID-19 & $\begin{array}{c}\text { Party } \\
\text { Activities }\end{array}$ & Personalities & $\begin{array}{l}\text { Election } \\
\text { Surveys }\end{array}$ \\
\hline $\begin{array}{l}\text { Frequency } \\
(\mathrm{N}=53)\end{array}$ & 2 & 2 & 4 & 1 & 9 & 7 & 4 & 3 \\
\hline $\begin{array}{l}\text { Percentage } \\
(\% \text { from } \mathrm{N})\end{array}$ & $3.8 \%$ & $3.8 \%$ & $7.5 \%$ & $1.9 \%$ & $17 \%$ & $13.2 \%$ & $7.5 \%$ & $5.7 \%$ \\
\hline Topic & $\begin{array}{c}\text { Political } \\
\text { Opponents }\end{array}$ & $\begin{array}{l}\text { Electoral } \\
\text { System }\end{array}$ & $\begin{array}{c}\text { Foreign Political } \\
\text { Events }\end{array}$ & $\begin{array}{l}\text { Political } \\
\text { Partners }\end{array}$ & $\begin{array}{l}\text { Historical } \\
\text { Events }\end{array}$ & Food Policy & $\begin{array}{c}\text { Transport } \\
\text { Policy }\end{array}$ & Economy \\
\hline $\begin{array}{l}\text { Frequency } \\
(\mathrm{N}=53)\end{array}$ & 1 & 5 & 2 & 4 & 2 & 1 & 2 & 4 \\
\hline $\begin{array}{l}\text { Percentage } \\
(\% \text { from } \mathrm{N})\end{array}$ & $1.9 \%$ & $9.4 \%$ & $3.8 \%$ & $7.5 \%$ & $3.8 \%$ & $1.9 \%$ & $3.8 \%$ & $7.5 \%$ \\
\hline
\end{tabular}

Source: author's processing based on posts published on the MSaN Facebook profile (MSaN 2021).

From the point of view of the frequency of expressions in keywords in the posts of MSaN, we identify the issue of elections to the Chamber of Deputies in the Czech Republic as the most important aspect. It is joined by pre-election coalition cooperation with the Pirate Party and the solution of the COVID-19 issue. Criticism is directed primarily at the current government. In quantitative indicators of the number of characters $(34,711)$ and words (9518), it significantly outperforms other monitored subjects. The frequency of keywords is illustrated in Table 26.

Table 26. Keywords in posts and their frequency-MSaN.

\begin{tabular}{cccccccc}
\hline Keyword & Frequency & Keyword & Frequency & Keyword & Frequency & Keyword & Frequency \\
\hline system & 21 & coalition & 14 & Pirati & 11 & situation & 9 \\
\hline STAN & 19 & pension & 13 & act & 10 & president & 9 \\
\hline election & 17 & young & 13 & planet & 9 & covid & 7 \\
\hline Emergency & 15 & mayors & 11 & party & 9 & republic & 6 \\
\hline
\end{tabular}

Evaluation of Political Communication of Czech Youth Political Organizations

Youth political organizations in the Czech Republic are actively involved in the ideological context of the functioning of this type of entity in society. Conflicts that are minimally present in inter-party struggles in socio-political events are shifting to struggles on an ideological level. We find disputes on the axis of conservatism vs. communism, or capitalism and communism, and the strengthening of its own ideological characteristics. In practice, they are based on various forms of internationalization, trade union movements, philosophical works, but also commemoration of historical events in the context of ideologies' impact. The sectoral solution of topics does not gain a significant position, with the exception of the issue of electoral legislation and elections to the Chamber of Deputies in the Czech Republic. The COVID-19 pandemic communication is regaining more prominence. Posts in this topic reflect on the emphasis on negative impacts on the economy, health care, or the importance of foreign solidarity. The educational nature of the posts is added in order to explain the meaning of the state of emergency or to provide real experience with traveling abroad. We place youth identity in the forefront of the distinguishing elements in the posts. The most frequent key words in the post of Czech youth political organisations are illustrated in Figure 2. 


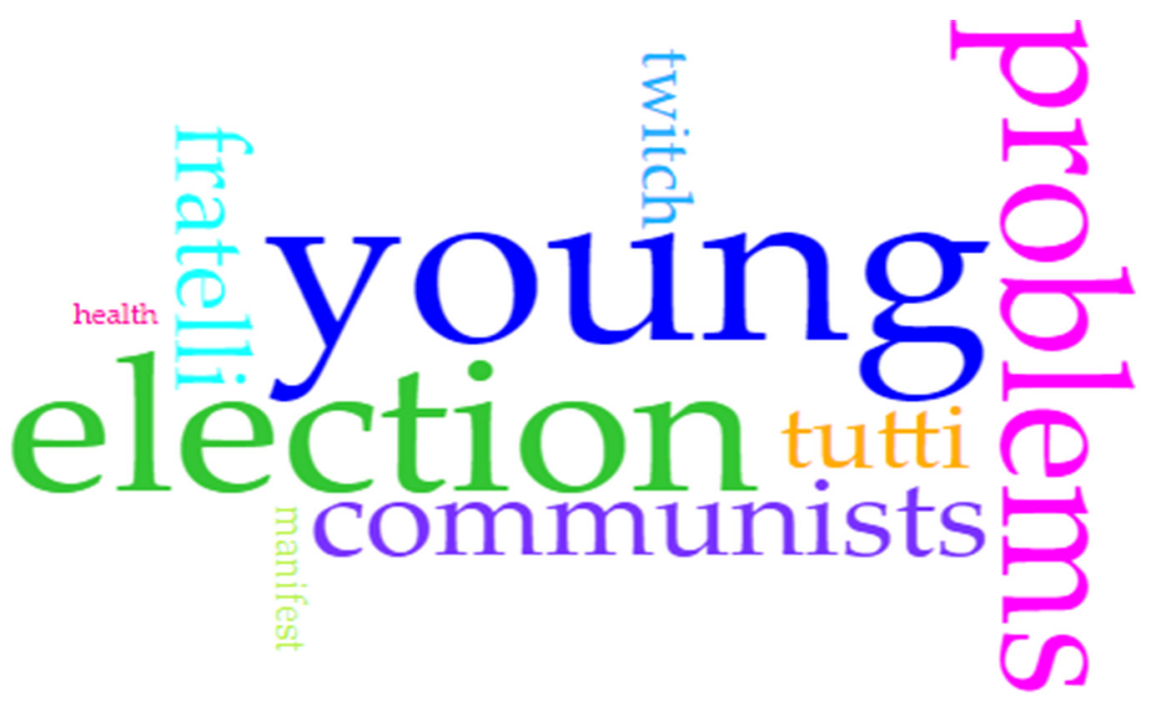

Figure 2. The most frequent keywords in the posts of Czech youth political organizations. Source: processing of the author on the basis of posts published on Facebook profiles (MSaN 2021; MSD-CR 2021; MOD 2021; ML 2021; MK 2021; MP 2021).

\subsection{European Youth Political Organizations}

European Liberal Youth-Youth Organization of the Alliance of Liberal and Democrats for Europe Party (Hereinafter Referred to as ELY)

The activities of the ELY youth organization and their presentation shape the key aspect of the published posts. They seek to recruit new members, send articles on EU and diplomacy from ELY and European liberal youth (LYMEC) members, present events that ELY members have managed to organize during the COVID-19 pandemic, or hold an ELY and LYMEC members' meeting in an online environment. Foreign policy in the EU is affecting events in Belarus, Russia, and Ukraine. ELY criticizes the imprisonment of A. Navalny in Russia and demands his release; on the contrary, it welcomes the withdrawal of the World Ice Hockey Championship in Belarus. In both cases, human rights violations are highlighted. It also sees the situation in Belarus with the prospect of protests, which led to a joint initiative of youth political organizations at EU level. In a joint statement, the youth organizations YDE, LYMEC, YES, YEF, EFAY, YEPP, IFLRY, and CAH express their support for the protesting people of Belarus in the fight for their human and political rights. The initiative is presented through \#StandWithBelarus. In the fight for human and women's rights, ELY issues an opinion in support of women in Poland. ELY perceives the political rights and democracy protection category sensitively through the events that took place in the USA during the attack on the Capitol. From the EU perspective they reflect the relationship between the EU and the United Kingdom and the negotiations after Brexit. ELY continues to see its UK partners as an important part of the youth family. In addition to emphasizing the different categories of rights, ELY also draws attention to the issues of environment, education, and the sustainable economy in the EU. In the case of the EU economy, a macroeconomic unemployment rate is highlighted. It focuses categorically on young people who are affected by job loss due to the COVID-19 pandemic. The frequency of topics is illustrated in Table 27. 
Table 27. Topics and frequency-ELY.

\begin{tabular}{|c|c|c|c|c|c|c|c|c|}
\hline Topic & Education & $\begin{array}{l}\text { Organization } \\
\text { Activities }\end{array}$ & $\begin{array}{c}\text { Partner } \\
\text { Organizations }\end{array}$ & $\begin{array}{l}\text { Socio-Political } \\
\text { Events EU }\end{array}$ & $\begin{array}{c}\text { Member Youth } \\
\text { Organizations }\end{array}$ & $\begin{array}{c}\text { Protests in } \\
\text { Belarus }\end{array}$ & Environment & $\begin{array}{c}\text { Human } \\
\text { Rights }\end{array}$ \\
\hline $\begin{array}{l}\text { Frequency } \\
(\mathrm{N}=39)\end{array}$ & 2 & 9 & 3 & 2 & 4 & 1 & 2 & 7 \\
\hline $\begin{array}{l}\text { Percentage } \\
(\% \text { from } \mathrm{N})\end{array}$ & $5.1 \%$ & $23 \%$ & $7.7 \%$ & $5.1 \%$ & $10.3 \%$ & $2.6 \%$ & $5.1 \%$ & 17.9 \\
\hline Topic & $\begin{array}{c}\text { Historical } \\
\text { Events }\end{array}$ & $\begin{array}{l}\text { Navalny- } \\
\text { Russia }\end{array}$ & Sport & Economy EU & $\begin{array}{c}\text { Foreign Policy } \\
\text { Outside EU }\end{array}$ & Brexit & & \\
\hline $\begin{array}{l}\text { Frequency } \\
(\mathrm{N}=39)\end{array}$ & 1 & 1 & 1 & 2 & 3 & 1 & & \\
\hline $\begin{array}{l}\text { Percentage } \\
(\% \text { from N) }\end{array}$ & $2.6 \%$ & $2.6 \%$ & $2.6 \%$ & $5.1 \%$ & $7.7 \%$ & $2.6 \%$ & & \\
\hline
\end{tabular}

Source: author's processing based on posts published on the ELY Facebook profile (ELY 2021).

The most important aspects according to keyword frequency highlight the youth organization itself and its two basic identifying elements, belonging to a liberal family and a European character. ELY's characteristics go on to specify the different categories of rights, primarily human rights that reflect what is happening in Belarus or Poland. ELY points to a common position with other youth organizations at EU level related to protests in Belarus to protect the human and political rights of the population through \#WeStandWithBelarus. An essential part is the presentation of various forms of activities, which are focused primarily on their members and member youth organizations. The number of characters $(10,329)$ and words (2146) shows a relatively sufficient level of post-processing quality. The interaction is ensured on a regular basis, while the contents of the posts communicate the most important information. The frequency of keywords is illustrated in Table 28.

Table 28. Keywords in posts and their frequency-ELY.

\begin{tabular}{cccccccc}
\hline Keyword & Frequency & Keyword & Frequency & Keyword & Frequency & Keyword & Frequency \\
\hline lymec & 22 & young & 13 & youth & 7 & article & 7 \\
\hline europe & 17 & event & 9 & women & 7 & register & 6 \\
\hline european & 15 & members & 8 & website & 7 & forum & deal \\
\hline liberal & 14 & libertas & 8 & rights & 7 & 6 \\
\hline
\end{tabular}

Source: author's processing based on posts published on the ELY Facebook profile (ELY 2021).

Federation of Young European Greens (Hereinafter Referred to as FYEG)

The youth political organization FYEG profiles itself as an entity with a strong emphasis on environmental issues. This fact is not only based on the name itself, but also declares active communication of the topic. FYEG considers cooperation and negotiations on the Green New Deal Act to be the basis for successful progress in environmental protection at EU level. The introduction of a new category of rights in the concept of Nature's Rights is innovative. The framework seeks to protect nature for future generations. In the field of environment and nature, FYEG is also working to transform into a fossil-free society and reduce the impact of climate change. The ideological nature of the organization is completed by eco-socialism with a bottom-up principle and expresses its affiliation with the left-wing spectrum of political organizations. On other socio-political topics, FYEG takes a stand on the quality of democracy and events in Belarus. It supports the citizens of Belarus in the \#WeStandWithBelarus initiative. The perspective of the quality of democracy is reflected in the shortcomings of authoritarian leaders who ignore respect for human rights. The human rights where FYEG feels its greatest shortcomings are the fight against racism, women's rights, transgender people, migrant rights, economic inequality, and LGBTI people. The communicated content is completed by the presentation of activities, 
either at the level of FYEG itself or in cooperation with other FYEG member organizations. The frequency of topics is illustrated in Table 29.

Table 29. Topics and frequency-FYEG.

\begin{tabular}{|c|c|c|c|c|c|c|c|c|}
\hline Topic & Environment & $\begin{array}{c}\text { Partner } \\
\text { Organisations }\end{array}$ & $\begin{array}{l}\text { Nature's } \\
\text { Rights }\end{array}$ & $\begin{array}{l}\text { Quality of } \\
\text { Democracy }\end{array}$ & $\begin{array}{l}\text { Protests in } \\
\text { Belarus }\end{array}$ & $\begin{array}{l}\text { Membership } \\
\text { in Youth } \\
\text { Organisation }\end{array}$ & $\begin{array}{l}\text { Human } \\
\text { Rights }\end{array}$ & $\begin{array}{c}\text { Organisation } \\
\text { Activities }\end{array}$ \\
\hline $\begin{array}{l}\text { Frequency } \\
(\mathrm{N}=25)\end{array}$ & 5 & 5 & 2 & 1 & 1 & 3 & 1 & 4 \\
\hline $\begin{array}{l}\text { Percentage } \\
(\% \text { from } \mathrm{N})\end{array}$ & $20 \%$ & $20 \%$ & $8 \%$ & $4 \%$ & $4 \%$ & $12 \%$ & $4 \%$ & $16 \%$ \\
\hline Topic & $\begin{array}{c}\text { Foreign Policy } \\
\text { Outside EU }\end{array}$ & EU Economy & COVID-19 & & & & & \\
\hline $\begin{array}{l}\text { Frequency } \\
(\mathrm{N}=25)\end{array}$ & 1 & 1 & 1 & & & & & \\
\hline $\begin{array}{l}\text { Percentage } \\
(\% \text { from N) }\end{array}$ & $4 \%$ & $4 \%$ & $4 \%$ & & & & & \\
\hline
\end{tabular}

Source: author's processing based on posts published on the FYEG Facebook profile (FYEG 2021).

Environmental protection represents the key message of FYEG communication. In particular, the youth organization calls for joint action to address the negative effects of climate change and the adoption of the concept of Nature's Rights. There is an emphasis on the youth and European nature. In addition to the environment, human rights and the protection of minorities in society are the second relevant FYEG topic. According to indicators of the number of characters $(11,766)$ and words $(2341)$, FYEG ranks approximately at the level of ELY. The posts try to emphasize the content and do not seek detailed explanations of the issue. The frequency of keywords is illustrated in Table 30.

Table 30. Keywords in posts and their frequency-FYEG.

\begin{tabular}{ccccccccc}
\hline Keyword & Frequency & Keyword & Frequency & Keyword & Frequency & Keyword & Frequency \\
\hline greens & 32 & together & 16 & climate & 9 & youngreen & 7 \\
\hline young & 25 & people & 11 & parliament & 8 & systematic & 7 & 7 \\
\hline green & 21 & europe & 11 & member & 8 & rights & perspective \\
\hline european & 19 & youth & 10 & change & 8 & & 7 \\
\hline
\end{tabular}

Source: author's processing based on posts published on the FYEG Facebook profile (FYEG 2021).

Young Democrats for Europe-European Democratic Party/ALDE (hereinafter referred to as YDE)

YDE does not appear to be an organization that emphasizes a certain group of topics in communication, as in the case of ELY or FYEG, which would profile it more significantly. The only characteristic and identifying element is democracy and its principles. As a youth organization uniting democrats, it seeks to spread the values that are characteristic of democratic regimes. Human dignity, the rule of law, freedom, equality, solidarity, and responsibility are the main principles on which the YDE wants to rebuild the EU and be its leading force. YDE seeks to present primarily its civic and democratic essence. YDE marginally touches on social media and the Internet. In this case, it appreciates the wider cooperation of youth organizations in the fight for a higher level of protection in the social media environment. In the rest of the political communication, it relies more on current socio-political events, which it complements with some important historical events. It highlights the conclusion of a bilateral friendship between France and Germany, which until now, according to the YDE, allows not only young people to gain new opportunities in education, work, and other social sectors. Aspects of peace and friendship are highlighted, which should also be the foundation of democracy. Like ELY and FYEG, YDE expresses its 
solidarity with the people of Belarus in the fight for their human and political rights. The frequency of topics is illustrated in Table 31.

Table 31. Topics and frequency-YDE.

\begin{tabular}{ccccccc}
\hline Topic & $\begin{array}{c}\text { Organization } \\
\text { Activities }\end{array}$ & $\begin{array}{c}\text { Protests in } \\
\text { Belarus }\end{array}$ & $\begin{array}{c}\text { Partner } \\
\text { Organisations }\end{array}$ & Education & $\begin{array}{c}\text { Historical } \\
\text { Events }\end{array}$ & $\begin{array}{c}\text { Socio-Political } \\
\text { Events in the EU }\end{array}$ \\
\hline $\begin{array}{c}\text { Frequency } \\
(\mathrm{N}=14)\end{array}$ & 5 & 2 & 3 & 2 & 1 & 1 \\
\hline $\begin{array}{c}\text { Percentage } \\
(\% \text { from } \mathrm{N})\end{array}$ & $36 \%$ & $14.2 \%$ & $21.4 \%$ & $14.2 \%$ & $7.1 \%$ & $7.1 \%$ \\
\hline
\end{tabular}

Source: author's processing based on posts published on the YDE Facebook profile (YDE 2021).

Democracy, youth, and the EU are the primary identifiers of YDE's political communication. We do not find a stronger presentation of sectoral topics or current political developments inside or outside the EU. The quality of post processing rates gets more to the core. We see the only exception through the reference to the German-French friendship of 1963. Friendship, peace, support, and cooperation as exemplary values of the functioning of society and bilateral partnership should, according to YDE, be a model for the further direction of the EU. The total length of all posts (1774 words and 8614 characters) does not stand out from other youth organizations. The frequency of keywords is illustrated in Table 32.

Table 32. Keywords in posts and their frequency-YDE.

\begin{tabular}{cccccccc}
\hline Keyword & Frequency & Keyword & Frequency & Keyword & Frequency & Keyword & Frequency \\
\hline european & 21 & youth & 12 & franco & 9 & support & 9 \\
\hline young & 18 & EU & 11 & winter & 8 & erasmus & 6 \\
\hline german & 13 & europe & 10 & political & 7 & YDE & EDP \\
\hline democrats & 13 & people & 9 & academy & 7 & 5 \\
\hline
\end{tabular}

Source: author's processing based on posts published on the YDE Facebook profile (YDE 2021).

Young European Federalist (hereinafter Referred to as YEF)

Democracy, the quality of democracy, and human rights express the main communication of the YEF. Addressing democracy issues is in line with the YDE, the nature of the posts has a different sense than the YDE. The concept of \#DemocracyUnderPressure is created, drawing attention to democratic deficits in selected countries in the EU and outside the EU. The various challenges of democratic regimes in Bulgaria, Russia, the United Kingdom, or Ukraine are discussed with the guests in the form of discussions. It does not point to more specific elements than in the case of YDE, although more cases of selected countries are used. Human rights are in the context of the quality of democracy. In this sense, the common position of European youth organizations under the slogan \#WeStandWithBelarus is the most popular. The transformation process of the transition from a communist establishment to a liberal democracy is based on the example of Hungary from 1989 to 1991. The federalist nature of the organization comes to life by depicting the election of Joe Biden as president in the USA. The YEF points to Joe Biden's federalist "mittens", it is the federation that should be the future of the EU. On complementary topics, the YEF takes a position on the environment and the sustainability of resources, the EU budget, and human rights. For the first time, from the perspective of a youth organization at EU level, we find commenting on funding in the EU budget. The EU budget emphasizes, in particular, the environmental component. The frequency of topics is illustrated in Table 33. 
Table 33. Topics and frequency-YEF.

\begin{tabular}{|c|c|c|c|c|c|c|c|c|}
\hline Topic & $\begin{array}{l}\text { The Quality } \\
\text { of Democracy }\end{array}$ & $\begin{array}{l}\text { Human } \\
\text { Rights }\end{array}$ & Education & $\begin{array}{c}\text { Protests in } \\
\text { Belarus }\end{array}$ & $\begin{array}{l}\text { Historical } \\
\text { Events }\end{array}$ & $\begin{array}{c}\text { Socio-Political } \\
\text { Events Outside } \\
\text { the EU }\end{array}$ & Environment & $\begin{array}{c}\text { Socio-Political } \\
\text { Events in the } \\
\text { EU }\end{array}$ \\
\hline $\begin{array}{l}\text { Frequency } \\
(\mathrm{N}=36)\end{array}$ & 9 & 5 & 4 & 3 & 1 & 3 & 3 & 1 \\
\hline $\begin{array}{l}\text { Percentage } \\
(\% \text { from N) }\end{array}$ & $25.1 \%$ & $13.9 \%$ & $11.1 \%$ & $8.3 \%$ & $2.8 \%$ & $8.3 \%$ & $8.3 \%$ & $2.8 \%$ \\
\hline Topic & COVID-19 & $\begin{array}{c}\text { Organization } \\
\text { Activities }\end{array}$ & Migration & & & & & \\
\hline $\begin{array}{l}\text { Frequency } \\
(\mathrm{N}=36)\end{array}$ & 1 & 4 & 2 & & & & & \\
\hline $\begin{array}{l}\text { Percentage } \\
(\% \text { from } \mathrm{N})\end{array}$ & $2.8 \%$ & $11.1 \%$ & $5.5 \%$ & & & & & \\
\hline
\end{tabular}

Source: author's processing based on posts published on the YEF Facebook profile (YEF 2021).

As in the case of YDE, we identify democracy as a key aspect. The YEF focuses more on bringing information in the form of discussions from selected countries. As in all previous cases, the European identity is clear. The nature of the posts also aims to highlight the future in the form of the federal establishment of the EU. In addition to democracy and federations, we also gain an overview of inclinations on environmental and sustainability issues. The evaluation of quantitative indicators (12,482 characters, 2418 words) of the processing of posts ranks YEF with a slight overlap relative to the level of FYEG and ELY. The frequency of keywords is illustrated in Table 34.

Table 34. Keywords in posts and their frequency-YEF.

\begin{tabular}{cccccccc}
\hline Keyword & Frequency & Keyword & Frequency & Keyword & Frequency & Keyword & Frequency \\
\hline europe & 27 & democracy & 9 & pressure & 7 & school & 5 \\
\hline european & 26 & today & 8 & parliament & 6 & presid & 5 \\
\hline project & 9 & policy & 8 & inclusion & 6 & discri & 5 \\
\hline democracy & 9 & future & 7 & united & 5 & confer & 5 \\
\hline
\end{tabular}

Source: author's processing based on posts published on the YEF Facebook profile (YEF 2021).

Youth European People's Party (Hereinafter Referred to as YEPP)

The COVID-19 pandemic has been mentioned only a minimal, marginal amount in the current youth political organizations. For YEPP, the SARS-COV-19 virus pandemic absolutely dominates. YEPP communicates the COVID-19 pandemic on several levels. The most important element highlights the nature and need for the vaccine. They mention vaccines' importance, safety, manufacturing process, EU financial support for development, benefits of vaccination, or achieving the highest possible vaccination success in society. YEPP has an exclusively positive attitude towards vaccination. In connection with the COVID-19 pandemic and vaccination, it draws attention to various misinformations that are spreading primarily in the online environment. As a prevention against the effects of misinformation, the YEPP recommends checking the information that users come into contact with. It also creates its own campaign via \#VaccinesWork for vaccinations. The last level in connection with the COVID-19 pandemic is the impact on the social systems of the EU Member States and the world in general in conjunction with the economic burden on budgets. In the field of health, in addition to the COVID-19 pandemic, YEPP focuses on addressing cancer-related deaths even more actively. In other topics, YEPP communicates only through the perspective of isolated reactions. It commemorates the Holocaust Remembrance Day; presents several activities of the organization and its partners; or, like all European youth political organizations to date, joins the people of Belarus through \#WeStandWithBelarus. The frequency of topics is illustrated in Table 35. 
Table 35. Topics and frequency-YEPP.

\begin{tabular}{|c|c|c|c|c|c|c|c|c|}
\hline Topic & $\begin{array}{c}\text { Human } \\
\text { Rights/Discrimination }\end{array}$ & COVID-19 & $\begin{array}{c}\text { Partner } \\
\text { Organisations }\end{array}$ & $\begin{array}{l}\text { Protests in } \\
\text { Belarus }\end{array}$ & Disinformation & $\begin{array}{l}\text { Health } \\
\text { Policy }\end{array}$ & $\begin{array}{l}\text { Historical } \\
\text { Events }\end{array}$ & $\begin{array}{c}\text { Organization } \\
\text { Activities }\end{array}$ \\
\hline $\begin{array}{l}\text { Frequency } \\
(\mathrm{N}=32)\end{array}$ & 1 & 16 & 1 & 1 & 1 & 4 & 1 & 2 \\
\hline $\begin{array}{l}\text { Percentage } \\
(\% \text { from N) }\end{array}$ & $3.1 \%$ & $50 \%$ & $3.1 \%$ & $3.1 \%$ & $3.1 \%$ & $12.8 \%$ & $3.1 \%$ & $6.2 \%$ \\
\hline Topic & $\begin{array}{l}\text { Socio-Political Events } \\
\text { Outside the EU }\end{array}$ & $\begin{array}{c}\text { Socio-Political } \\
\text { Events in the EU }\end{array}$ & Environment & & & & & \\
\hline $\begin{array}{l}\text { Frequency } \\
(\mathrm{N}=32)\end{array}$ & 1 & 2 & 2 & & & & & \\
\hline $\begin{array}{l}\text { Percentage } \\
(\% \text { from N) }\end{array}$ & $3.1 \%$ & $6.2 \%$ & $6.2 \%$ & & & & & \\
\hline
\end{tabular}

Source: author's processing based on contributions published on the YEPP Facebook profile (YEPP 2021).

The terms vaccine, vaccination, and \#VaccineWork stand out most prominently in YEPP communication. Compared to other youth organizations in a transnational environment, YEPP places the highest emphasis on the COVID-19 pandemic and the need for vaccination. In the field of health and healthcare, it shows additional activity with an emphasis on deaths caused by cancer. It often tries to emphasize its own identity with European transnationality. Communication in the monitored period in 8303 characters and 1648 words is completed by various aspects of the impacts of the COVID-19 pandemic, such as disinformation and the burden on the economies of states or their social systems. The frequency of keywords is illustrated in Table 36.

Table 36. Keywords in posts and their frequency-YEPP.

\begin{tabular}{ccccccccc}
\hline Keyword & Frequency & Keyword & Frequency & Keyword & Frequency & Keyword & Frequency \\
\hline vaccinework & 15 & YEPP & 11 & check & 7 & pande & 5 \\
\hline vaccine & 13 & vaccines & 8 & cancer & 7 & econo & 5 \\
\hline health & 13 & president & 7 & healthy & 6 & covid & 5 \\
\hline european & 12 & disinformation & 7 & vaccinat & 5 & youth & 4 \\
\hline
\end{tabular}

Source: author's processing based on posts published on the YEPP Facebook profile (YEPP 2021).

Young European Socialists (Hereinafter Referred to as YES)

YES communication activity shows the lowest level of interactivity with the audience. The discussion of political topics remains in the background and the presentation of the organization's activities comes to the fore. YES, like FYEG, has a positive view of the Green New Deal activity. In addition to organizations in the traditional left-wing spectrum, this fact brings YES closer to representatives with the primary issues of the environment and environmentalism. In other ideological and ideological levels, YES is not presented in the observed period. It also points to the importance of commemorating the Holocaust Memorial Day, when people who differed, for example, in their political attitudes, religion, or sexuality, died. We identify the last set of content in the form of an emphasis on youth education. YES is also involved in \#WeStandWithBelarus. The frequency of topics is illustrated in Table 37. 
Table 37. Topics and frequency-YES.

\begin{tabular}{|c|c|c|c|c|c|}
\hline Topic & Environment & $\begin{array}{l}\text { Organization } \\
\text { Activities }\end{array}$ & Education & $\begin{array}{l}\text { Historical } \\
\text { Events }\end{array}$ & $\begin{array}{c}\text { Partner } \\
\text { Organisations }\end{array}$ \\
\hline $\begin{array}{l}\text { Frequency } \\
\quad(\mathrm{N}=8)\end{array}$ & 1 & 3 & 2 & 1 & 1 \\
\hline $\begin{array}{l}\text { Percentage } \\
(\% \text { from N) }\end{array}$ & $12.5 \%$ & $37.5 \%$ & $25 \%$ & $12.5 \%$ & $12.5 \%$ \\
\hline
\end{tabular}

Processing quality and frequency (1601 characters and 272 words) shows the lowest values in comparison. In the short posts, we find, in addition to a narrow range of topics, the emphasis on socialist, left-wing identity, supplemented by the youthful nature. YES is active in highlighting the Holocaust, with particular emphasis on the causes of death. The frequency of keywords is illustrated in Table 38.

Table 38. Keywords in posts and their frequency-YES.

\begin{tabular}{ccccccccc}
\hline Keyword & Frequency & Keyword & Frequency & Keyword & Frequency & Keyword & Frequency \\
\hline education & 4 & students & 2 & murdered & 2 & together & 1 \\
\hline young & 3 & organisation & 2 & member & 2 & sexualit & 1 \\
\hline socialists & 3 & network & 2 & itnernation & 2 & session & 1 \\
\hline youth & 2 & nazi & 2 & Withbelarus & 1 & seminar & 1 \\
\hline
\end{tabular}

Source: author's processing based on posts published on the YES Facebook profile (YES 2021).

Evaluation of the Political Communication of European Youth Political Organizations

A common communication element that occurs across the spectrum of European youth political organizations is the use of the \#hashtag symbol. Live themes in connection with the Instagram social network create one joint activity of all organizations in the form of \#WeStandWithBelarus (ELY, FYEG, YDE, JEF, YES and YEPP) and two individual \#DemocracyUnderPressure (JEF) and \#VaccinesWork (YEPP). The aforementioned joint initiative \#WeStandWithBelarus, which aims to express the support of the people of Belarus in the fight for their human and political rights, stands out for its uniqueness. The category of human rights in connection with specific target groups and minorities are another important element of communication. According to organizations, the need to improve human rights is necessary for women, LGBTI minorities, or migrants. There is also a need to address economic inequality and the fight against racism. The ideological context manifests itself only in the case of FYEG eco-socialism. On the contrary, democracy and the quality of democracy are gaining a more significant communication space, as has also been indicated through the \#DemocracyUnderPressure. Environmental issues significantly dominate the overall package of sectoral themes. In this context, the innovative creation of a group of rights called Nature's Rights and the cooperation of major European political parties and factions on the Green New Deal is visible. There are three basic identification elements available at all youth organizations: youth nature, European affiliation, and ideological characteristics. The most frequent keywords in the posts of youth political organizations at European level are illustrated in Figure 3. 


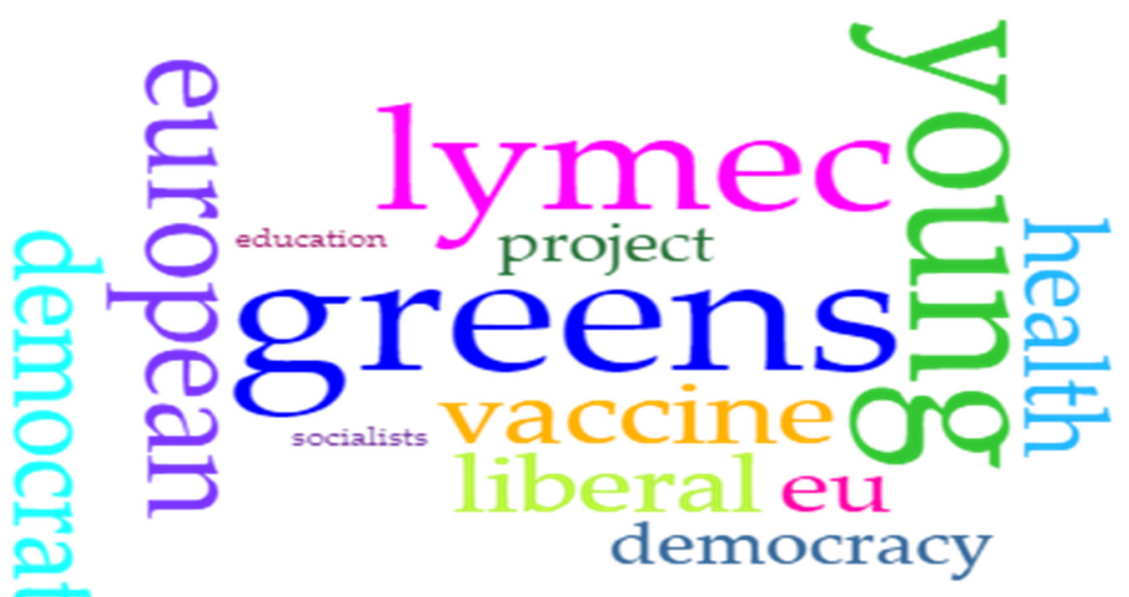

Figure 3. The most frequent keywords in the posts of youth political organizations at European level. Source: author's processing based on the posts published on Facebook profiles.

\section{Discussion \& Conclusions}

The study results extend the current state of political communication research. It focuses exclusively on the environment of Facebook and does not combine several electronic platforms or social networks. It follows the path of a detailed quantitative-qualitative analysis of official Facebook profiles. The research does not follow the national view but offers a multi-level cross-case comparison. It goes beyond the traditional style of concentrating on the single case study. It tries to follow up on a set of studies from the Central European region (or Eastern European region) (Plichtová and Šestáková 2019; Mihálik and Jankol'a 2020; Filipec et al. 2018; Mihálik and Walter 2018; Annusewicz and Morawski 2014) and at the other hand it is in direct confrontation with the transnational European dimension. We follow the social media Facebook research similar to Cervi et al. (2021a); López-Meri et al. (2017); Mihálik et al. (2020); and Mihálik and Džačovský (2018). The specificity is also reflected in the selection of the monitored time period. According to the structure of selected levels, it does not evaluate the time period related to any types of elections. At the same time it provides insight into inter-election communication strategies. The purpose of discovering all topics and actors is to try and identify any categories of similarities or differences. The explorative character of study does not follow the way of selected data based on predefined keywords, topics, actors, or attached URL links. Depending on the category of target subjects, the study fits into the context of political parties-organizations. The relatively innovative approach is to focus on the supporting organizational units of political parties and youth political organizations while the number of studies related exclusively to YPO is significantly low. On the other hand, the main political parties and representatives of political parties are not completely detached. They created direct components of the analysis results.

The topics monitoring brings several levels of findings. From all sort of identified topics, COVID-19 has a dominant and leading position. It appears to be a 'hot-topic' from two sides of perspective: the number of YPOs communicating the topic (72\% of cases) and the overall frequency of occurrence of the topic compared to other topics. The COVID-19 topic takes various forms as is communicated by the YPOs. At the national level of YPOs, the attitude-based types of posts are mostly visible. These are, in most cases, dedicated to government measures to prevent the spread of the virus. In this case YPOs positions are strictly antagonistic. The first group only criticizes the taken measures, the second group calls for strict compliance and supports the measures. The position of YPOs is almost identical to the position of their parent political parties. Parties (and their YPOs) with coalition status defend the measures, while the opposition subjects are in conflicts. Extra category represents YPOs with their political party out of parliament. One Slovak YPO 
holds positions with support to the restrictions (KDMS). The results record certain statistical exceptions, when YPO criticizes their main party coalition partner: the purchase of Sputnik $\mathrm{V}$ vaccines (MZL' vs. OL'aNO) or for some restrictions (MSaS vs. OL'aNO). Specific cases of neutral posts are also present. This type of post aims to highlight existing misinformation connected to COVID-19, to provide information on current scientific knowledge or to explain the implementation of certain measures. At the transnational level, COVID-19 is not the top communicated topic. It is included in 33\% of YPOs compared to $100 \%$ of YPOs in Slovakia and 83\% in Czechia. Compared to the national level, results do not confirm any kind of criticism or support for action at EU or against any European states. The posts are aiming $t$ the impacts and consequences that COVID-19 causes: job loss, online work performance, and travel restrictions. A strong accent is identified with YEPP in the case of vaccines. They emphasize positive and important role of vaccines. YEPP strengthens communication through the \#VaccineWorks campaign.

The next level of communicated topics is primarily related to various sectoral public policies. Again, results find a different range of topics and their forms at the national and transnational levels. Another important difference between the national and supranational YPO is the communication of international political affairs. At the national level, YPOs focus exclusively on the domestic political scene and related events. The Slovak YPOs deal mainly with the ongoing population census. The Czech YPOs focused mostly on the electoral system of parliament. Despite the membership of the Slovakia and the Czechia in the EU, the possible Europeanization or internationalization of posts in the observed period is not proven in almost any Slovak and Czech YPO. Exception is represented by MSaN commenting on what is happening in Russia (the imprisonment of Alexei Navalny) and in the USA (the winner of the US presidential elections being Joe Biden).

At the supranational level, results record foreign policy issues as the primary communicated topic. Issues are mainly related to the Ukraine, Belarus, and Russia. The events in Belarus have received significant attention from all YPOs at the European level. Identified posts express a supportive attitude for the opposition in Belarus. YPOs use an enhanced form of campaign through \#WeStandWithBelarus. The complex is completed by the communication of sectoral themes concentrated in three areas: the environment connected with Green New Deal, democracy and its principles, and human rights. The presentation of these topics follows the ideological base of YPOs. FYEG and YES pay attention to the Green New Deal, ELY and FYEG highlight human and women's rights, and finally YDE and YEF reflect on the principles of democracy. YDE and YEF link democracy deficits with the communication of events in Belarus. In addition, results show presence of \#DemocracyUnderPressure and \#StandWithBelarus campaigns. The use of trend themes represents the only link between the transnational and national levels. Monitoring determines the presence of marijuana decriminalization (MSaS), environmental (KDMS), animal protection (MP), and food policy (MP) topics. In comparison with the transnational dimension, the topics are linked to the ideological base of YPOs. The last topic dimension is represented by ideologies and its elements. These occur on both levels, more significantly at national YPOs. In this case, posts are available in two opinion forms. The purpose of the first form is to defend a specific ideology (MK, MSD-SR, MSaS, L'M). The second form seeks to argue against ideology and its elements (MSaS vs. socialism; ML vs. communism; MSaS vs. conservatism/Christian democracy). Regardless of attitudes, analysis records comments to the ideologies of communism (MK), socialism/social democracy (FYEG, MSaS, MSD-SR), liberalism (ELY, MSaS), Christian democracy/conservatism (ML), nationalism (LM), and environmentalism (FYEG, KDMS, MP).

The second key analysis part of included actors identified three main categories of YPOs attention: individuals-politicians; individual institutions-political parties/YPOs; and collective bodies-governments. The national-level YPOs tend more likely to an actorbased approach in communication strategies. Again, the results show positive or negative positions posts. Neutral forms are not incorporated in this case. Two types of strategies are used to include individuals-politicians. The first one uses current or former repre- 
sentatives of political parties to receive positive feedback to the YPO (KDMS). The second form contains criticism to representatives from rival political parties (MSaS). The support or criticism primarily has connection with the positions of the main political parties of the YPOs. The cooperation of political parties is also transferred to the cooperation between the YPOs. The same form is proven in the case of criticism. The addition for this case is also an aspect of coalition or opposition status in national parliament. On the other hand, two specific exceptions are available in the Slovak YPOs: MSaS, whose political party SaS has coalition status, criticizes another coalition partner, the OL'aNO party. Similarly, YPO MZL' (Za l'udí party) is in conflict with the OL'aNO political party (coalition partner). The last element on which support or criticism is based represents the ideological context. There are conflicts between the left and the center-right parties (MSD-SR vs. MSaS; MSaS vs. MSD-SR, Hlas-SD and Smer-SD; MZL' vs. Smer-SD, Hlas-SD; MSD-CR vs. ODS), socialism/social democracy and conservatism (ML vs. MK), and socialism/social democracy and nationalism (MSD-CR vs. SPD). As an interesting result, we can describe criticism of the LM (conservative/nationalist YPO) towards other political parties in the conservative/nationalist positions. In this case, it is a general criticism without defining specific subjects. The perspective of collective bodies (government) is based exclusively on criticism. These are mainly related to the mentioned COVID-19 topic and the measures taken by the government. The primary criticism comes from opposition actors. At the transnational level, a unique form of YPO cooperation has been created in the case of the \#WeStandWithBelarus campaign. The joint initiative was created by all YPOs, regardless of the ideological base and position in the party system. The campaign presents the names of all YPOs, which gradually appeared in the posts on all FB profiles. Other forms of involvement of actors at the transnational level have not been demonstrated in the results.

There are limited possibilities in confrontation with the results of the current state of research. This statement is exacerbated by the fact that there are few studies that would focus their interest on youth political organizations in political communication. For this reason, too, the study meets its exploratory nature. Following Mihálik et al. (2020), the communication of the COVID-19 topic of the Slovak YPOs was confirmed. The difference is the change in the frequency of communication of the topic. While in 2020 YPOs approached the topic more passively, currently the topic is communicated by Slovak YPOs above average. With the Czech and EU YPOs, this fact cannot be confronted due to the absence of similar studies. In addition to the topic of COVID-19, it is still possible for the Slovak YPOs to confront the implementation of actors in political communication. As in the case of the results of Mihálik et al. (2020), it is also an active part. It acquires equally positive or negative saturation towards other actors. It is not possible to compare the frequencies with each other on the basis of other methodological procedures.

In the context of confrontations, it is possible to compare some other elements. While the study focuses on an approach exploring the topics and actors, in other studies the authors focus on other approaches such as content distribution, emotions (Cervi et al. 2021b), interactions, or posts structure (Cervi and Marín-Lladó 2021). COVID-19 is used as a topic approach by Cervi et al. (2021a). In comparison, COVID-19 topic manifests itself as an important communication determinant. Cervi et al. (2021a) points to the populist use of COVID-19 with an emphasis on beatific and horrific emphasis. There is also a difference in the focus on subject. Cervi et al. (2021a) analyzed Trump and Bolsonaro communication. In addition to political communication, the research also focuses on campaigns (Dimitrova and Matthes 2018; Bossetta 2018; Jungherr 2016) and political participation (Haro-de-Rosario et al. 2018; de Zúñiga et al. 2012; Moeller et al. 2014). It remains important to state there is a focus on either the main political parties (Jungherr 2016), individual actors (de Zúñiga et al. 2012; Jungherr 2016), or citizens (Haro-de-Rosario et al. 2018; Moeller et al. 2014). From this point of view, the results of the mentioned studies cannot be confronted with our research since there is a lack of known context of the use of social networks, such as Facebook in our case. 


\begin{abstract}
Author Contributions: Conceptualization, M.G., J.B. and J.M.; methodology, M.G.; validation, M.G. and J.B.; formal analysis, M.G.; resources, M.G., J.B. and J.M.; data curation, M.G.; writing-original draft preparation, M.G.; writing—review and editing, J.B., J.M.; visualization, M.G.; supervision, J.M.; project administration, J.M.; funding acquisition, J.M. All authors have read and agreed to the published version of the manuscript.
\end{abstract}

Funding: This research was funded by Scientific Grant Agency of the Slovak Republic grant number 1/0458/20: Youth organizations in political party systems: national and supranational dimension.

Conflicts of Interest: The authors declare no conflict of interest.

\title{
References
}

Allcott, Hunt, and Matthew Gentzkow. 2017. Social Media and Fake News in the 2016 Election. Journal of Economic Perspectives 31: 211-36. [CrossRef]

Annusewicz, Olgierd, and Antoni Morawski. 2014. Social Media in Political Communication in Central Europe-Quantitative Analysis. Social Media Political Index 2014. Kwartalnik Naukowy OAP UW e-Politikon 9: 9-42.

Bagić Babac, Marina, and Vedran Podobnik. 2018. What social media activities reveal about election results? The use of Facebook during the 2015 general election campaign in Croatia. Information Technology E People 31: 327-47. [CrossRef]

Bardovič, Jakub. 2018. Political Communication of MPs of the People's Party-Our Slovakia in Digital Area. In Marketing Identity. Digital Mirrors-Part I. Trnava: Faculty of Mass Media Communication, University of Ss. Cyril and Methodius in Trnava, pp. 25-35, ISBN 978-80-8105-984-1.

Bossetta, Michael. 2018. The Digital Architectures of Social Media: Comparing Political Campaigning on Facebook, Twitter, Instagram, and Snapchat in the 2016 U.S. Election. Journalism \& Mass Communication Quarterly 95: 471-96. [CrossRef]

Bratková, Katarína. V. 2015. The Use of Digital Mass Media by Top Officials of the Slovak Republic. In Marketing Identity. Trnava: Faculty of Mass Media Communication, University of Ss. Cyril and Methodius in Trnava, pp. 16-27.

Brunnerová, Olga, and Jakub Charvát. 2017. Metody výzkumu politické komunikace v nových médiích: Přehledová studie. Politické Vedy 20: 116-49.

Ceccobelli, Diego. 2018. Not every day is Election Day: A comparative analysis of eighteen election campaigns on Facebook. Journal of Information Technology \& Politics 15: 122-41. [CrossRef]

Cervi, Laura, and Carles Marín-Lladó. 2021. What are political parties doing on TikTok? The Spanish case. Profesional de la Información 30: 1-17. [CrossRef]

Cervi, Laura, Fernando García, and Carles Marín Lladó. 2021a. Populism, Twitter, and COVID-19: Narrative, Fantasies, and Desires. Social Sciences 10: 294. [CrossRef]

Cervi, Laura, Santiago Tejedor, and Carles Marín Lladó. 2021b. TikTok and the new language of political communication: The case of Podemos. Cultura, Lenguaje y Representación XXVI: 267-87. [CrossRef]

Daško, Martin. 2018. Local Action Groups in Slovakia on Facebook-The Real Mirror of their Activities. In Marketing Identity. Digital Mirrors-Part I. Trnava: Faculty of Mass Media Communication, University of Ss. Cyril and Methodius in Trnava, pp. 48-58, ISBN 978-80-8105-984-1.

de Zúñiga, Homero Gil, Nakwon Jung, and Sebastián Valenzuela. 2012. Social Media Use for News and Individuals' Social Capital, Civic Engagement and Political Participation. Journal of Computer-Mediated Communication 17: 319-36. [CrossRef]

Dimitrova, Daniela V., and Jörg Matthes. 2018. Social Media in Political Campaigning Around the World: Theoretical and Methodological Challenges. Journalism \& Mass Communication Quarterly 95: 333-42. [CrossRef]

Duffeková, Katarína. 2020. Zastúpenie politických subjektov a politikov v televíznom spravodajstve pred parlamentnými vol’bami 2020. In Publicy 2020 II-Sekcia Parlamentné vol'by a Sociálna Politika. Trnava: Fakulta Sociálnych Vied, Univerzita sv. Cyrila a Metoda v Trnave, pp. 35-46, ISBN 978-80-572-0090-1.

European Liberal Youth-Youth Organisation of Alliance of Liberal and Democrats for Europe Party. 2021. Available online: https: / / www.facebook.com/EuropeanLiberalYouthLYMEC (accessed on 2 June 2021).

Federation of Young European Greens. 2021. Available online: https://www.facebook.com/federationofyoungeuropeangreens (accessed on 2 June 2021).

Filipec, Ondřej. 2018. The Facebook Communication of the Far-Right Political Parties in the Czech Republic before the 2017 Elections to the Chamber of Deputies. In Marketing Idendity Digital Mirrors-Part II. Trnava: Faculty of Mass Media Communication, University of Ss. Cyril and Methodius in Trnava, pp. 73-80, ISBN 978-80-8105-985-8.

Filipec, Ondřej, Michal Garaj, and Jaroslav Mihálik. 2018. Ako komunikuje pravica: Komunikačné aktivity vybraných (krajne) pravicových politických strán v Českej republike a na Slovensku pred parlamentnými vol'bami v rokoch 2016 a 2017. Politické Vedy 21: 183-212. [CrossRef]

Garaj, Michal. 2018. Facebook in use of Political Parties in Slovakia-Tool for Communication of Promotion: Far Right vs. Others. In Marketing Idendity. Digital Mirrors-Part II. Trnava: Faculty of Mass Media Communication University of Ss. Cyril and Methodius in Trnava, pp. 98-108, ISBN 978-80-8105-985-8. 
Garaj, Michal, and Jakub Bardovič. 2020. Slovak 2019 Presidential Election and E-communication. In Marketing Identity: COVID2.0: Conference Proceedings from the International Scientific Conference. Trnava: Fakulta Masmediálnej Komunikácie, pp. 78-88, ISBN 978-80-572-0107-6.

Gbúrová, Marcela. 2006. Politické Strany v SR na Ceste k Politike Štandardu I. Available online: http://www.noveslovo.sk/node/17223 (accessed on 10 October 2021).

Gerodimos, Roman, and Jákup Justinussen. 2014. Political Communication in the Age of the Like Button. Journal of Information Technology E Politics 12: 113-32. [CrossRef]

Guiora, Amos, and Elizabeth A. Park. 2017. Hate Speech on Social Media. Philosophia 45: 957-71. [CrossRef]

Haro-de-Rosario, Arturo, Alejandro Sáez-Martín, and María del Carmen Caba-Pérez. 2018. Using social media to enhance citizen engagement with local government: Twitter or Facebook? New Media E Society 20: 29-49. [CrossRef]

Imrovič, Michal, Michal Lukáč, and Matúš Jankol'a. 2018. Blog Marketing as a Positive or Negative Phenomenon in Political Communication? Slovak Journal of Political Sciences 18: 180-94.

Jánošová, Denisa, and Renáta Bundzíková. 2020. Marketing Communication of Selected Conservative and Liberal Parties in Slovak Region Before Elections. Political Preferences 26: 27-40. [CrossRef]

Jungherr, Andreas. 2016. Twitter use in election campaigns: A systematic literature review. Journal of Information Technology $\mathcal{E}$ Politics 13: 72-91. [CrossRef]

Kaid, Lynda Lee. 2004. Introduction and Overview of the Field. In Handbook of Political Communication Research. Hillsdale: Lawrence Erlbaum Associates, pp. xiii-xviii, ISBN 0-8058-3774-4.

KDMS/Krest'ansko-Demokratická Mládež Slovenska (Christian Democratic Youth of Slovakia). 2021. Available online: https: / / www.facebook.com/KDMSonline (accessed on 6 June 2021).

Klinger, Ulrike, and Jakob Svensson. 2015. The emergence of network media logic in political communication: A theoretical approach. New Media \& Society 17: 1241-57. [CrossRef]

Kluknavská, Alena, and Matej Hruška. 2019. We Talk about the "Others” and You Listen Closely. Problems of Post-Communism 66: 59-70. [CrossRef]

Kyška, Roland. 2014. On Selected Aspects of the Methodology of Social Media Surveying from the Viewpoint of Political Sciences. Communication Today 5: 67-78.

Lincényi, Marcel, and Jaroslav Čársky. 2019. Prezidentské vol’by 2019 a politická kampaň. In Publicy 2019. Trnava: Fakulta sociálnych vied, Univerzita sv. Cyrila a Metoda v Trnave, pp. 38-45, ISBN 978-80-572-0016-1.

LM/L'udová Mládež (People's Youth). 2021. Available online: https:/ /www.facebook.com/ludovamladez (accessed on 24 March 2021).

López-Meri, Amparo, Silvia Marcos-García, and Andreu Casero-Ripollés. 2017. What do politicians do on Twitter? Functions and communication strategies in the Spanish electoral campaign of 2016. El Profesional de la Información 26: 795-804. [CrossRef]

Magin, Melanie, Nicole Podschuweit, Jörg Haßler, and Uta Russmann. 2016. Campaigning in the fourth age of political communication. A multi-method study on the use of Facebook by German and Austrian parties in the 2013 national election campaigns. Information, Communication \& Society 20: 1698-719. [CrossRef]

Mihálik, Jaroslav, and Aaron T. Walter. 2018. Masks and Mirrors: The Use of Social Media by Far-Right Political Parties and Movements in the Czech Republic and Slovakia. In Marketing Idendity. Digital Mirrors-Part II. Trnava: Faculty of Mass Media Communication University of Ss. Cyril and Methodius in Trnava, pp. 168-75, ISBN 978-80-8105-985-8.

Mihálik, Jaroslav, and Matúš Jankol'a. 2020. Stereotypy politického líderstva: Mediálna prezentácia lídrov politických strán na Slovensku a v Českej republike. In Publicy 2020 II.-Sekcia Parlamentné vol'by a Sociálna Politika. Trnava: Fakulta sociálnych vied, Univerzita sv. Cyrila a Metoda v Trnave, pp. 105-15, ISBN 978-80-572-0090-1.

Mihálik, Jaroslav, and Tomáš Džačovský. 2018. Social Media as a Mediator of Political Ideas in European Context. In Marketing Idendity. Digital Mirrors-Part II. Trnava: Faculty of Mass Media Communication, University of Ss. Cyril and Methodius in Trnava, pp. 62-72, ISBN 978-80-8105-985-8.

Mihálik, Jaroslav, Jakub Bardovič, and Michal Garaj. 2020. Social media of youth political organizations in times of COVID-19. In Marketing Identity COVID-2.0: Conference Proceedings from the Annual International Scientific Conference. Trnava: Fakulta Masmediálnej Komunikácie, pp. 419-29, ISBN 978-80-572-0107-6.

Mital', Ondrej. 2021. Transparency and Authenticity of Social Media Usage: The Case of Slovak Cities. Journal of Public Administration, Finance and Law 22: 42-55. [CrossRef]

MK/Mladí Komunisté KSČM (Young Communists KSČM). 2021. Available online: https:/ / www.facebook.com/mladikomunisteKSCM (accessed on 26 April 2021).

ML/Mladí Lidovci (Young People's Party). 2021. Available online: https:/ /www.facebook.com/MladiLidovci (accessed on 29 March 2021).

MOD/MladíObčanští Demokraté (Young Civic Democrats). 2021. Available online: https:/ / www.facebook.com/MladiObcanstiDemokrate/ (accessed on 29 March 2021).

Moeller, Judith, Claes de Vreese, Frank Esser, and Ruth Kunz. 2014. Pathway to Political Participation: The Influence of Online and Offline News Media on Internal Efficacy and Turnout of First-Time Voters. American Behavioral Scientist 58: 689-700. [CrossRef]

Momoc, Antonio. 2018. Populism 2.0, Digital Democracy and the New 'Enemies of the People'. Communication Today 9: 59-76.

MP/Mladé Pirátstvo (Young Piracy). 2021. Available online: https:/ / www.facebook.com/mladepiratstvo (accessed on 29 March 2021). 
MP-SR/Mladí Pomáhajú-Sme Rodina (Young People Help-We are Family). 2021. Available online: https://www.facebook.com/ mladipomahaju (accessed on 24 March 2021).

MS/Mladí SaSkári (Young SaS). 2021. Available online: https:/ / www.facebook.com/mladisas/ (accessed on 24 March 2021).

MSaN/Mladí Starostové a Nezávislí (Young Mayors and Independents). 2021. Available online: https://www.facebook.com/mSTAN. Praha (accessed on 29 March 2021).

MSD-CR/Mladí Sociální Demokraté (Young Social Democrats-CR). 2021. Available online: https://www.facebook.com/mladi.socdem/ (accessed on 29 March 2021).

MSD-SR/Mladí Sociálni Demokrati (Young Social Democrats-SR). 2021. Available online: https://www.facebook.com/ mladisocialnidemokrati (accessed on 29 March 2021).

Murár, Peter. 2011. Komunálne vol’by 2010 v prostredí sociálnych médií. Communication Today 2: 95-110.

MZL/Mladí Za l'udí (Young For People). 2021. Available online: https:/ /www.facebook.com/mladizaludi/ (accessed on 29 March 2021).

Norris, Pippa. 2015. Political Communication. In International Encyclopedia of the Social E Behavioral Sciences, 2nd ed. Amsterdam: Elsevier, pp. 342-49, ISBN 978-0-08-097087-5.

Nulty, Paul, Yannis Theocharis, Sebastian Adrian Popa, Olivier Parnet, and Kenneth Benoti. 2016. Social Media and Political Communication in the 2014 Elections to the European Parliament. Electoral Studies 44: 429-44. [CrossRef]

Ondrášik, Branislav. 2009. Political Marketing and its Professionalization: Ten Years of Campaigning for Slovak Presidency (1999, 2004 and 2009). Slovenská Politologická Revue 9: 2-30.

Ostrá, Daniela. 2021. Professionalization of Political Campaigns: Roadmap for the Analysis. Slovak Journal of Political Sciences 21: 5-26. [CrossRef]

Papacharissi, Zizi. 2004. Democracy online: Civility, politeness, and the democratic potential of online political discussion groups. New Media \& Society 6: 259-83. [CrossRef]

Plichtová, Jana, and Anna Šestáková. 2019. Diskurzívna analýza predvolebnej diskusie kandidátov na prezidenta SR z hl'adiska princípov deliberatívnej etiky. In Publicy 2019. Trnava: Fakulta sociálnych vied, Univerzita sv. Cyrila a Metoda v Trnave, pp. 46-60, ISBN 978-80-572-0016-1.

Smolková, Eva, and Peter Štarchoň. 2019. Specifics of Marketing Communications Within Political Environment in Slovakia. In Eurasian Business Perspectives. Eurasian Studies in Business and Economics. Edited by Mehmet Huseyin Bilgin, Hakan Danis, Ender Demir and Ugur Can. Cham: Springer, vol. 11, ISBN 978-3-030-18651-7. [CrossRef]

Stieglitz, Stefan, and Linh Dang-Xuan. 2012. Social Media and Political Communication-A Social Media Analytics Framework. Social Network Analysis and Mining 3: 1277-91. [CrossRef]

Stier, Sebastian, Arnim Bleier, Haiko Lietz, and Markus Strohmaier. 2018. Election Campaigning on Social Media: Politicians, Audiences, and the Mediation of Political Communication on Facebook and Twitter. Political Communication 35: 50-74. [CrossRef]

Young Democrats for Europe-European Democratic Party. 2021. Available online: https://www.facebook.com/YoungDemsEurope (accessed on 2 March 2021).

Young European Federalist. 2021. Available online: https:/ /www.facebook.com/JEFEurope (accessed on 2 March 2021).

Young European Socialists. 2021. Available online: https://www.facebook.com/youngsocialists (accessed on 2 March 2021).

Youth of the European People's Party. 2021. Available online: https:/ /www.facebook.com/youthepp (accessed on 2 March 2021).

Žúborová, Viera, and Milan Žúbor. 2013. Metodický pohl'ad na funkciu a činnost' webových stránok politických strán v podmienkach Slovenskej republiky. Slovak Journal of Political Sciences 13: 305-29. 